\title{
Radionuclide Concentrations in White Sturgeon from the Columbia River
}

D. D. Dauble

K. R. Price

T. M. Poston

September 1992

Prepared for the U.S. Department of Energy under Contract DE-AC06-76RLO 1830

Pacific Northwest Laboratory

Operated for the U.S. Department of Energy

by Battelle Memorial Institute 


\title{
DISCLAIMER
}

This report was prepared as an account of work sponsored by an agency of the United States Covernment. Neither the United States Government nor any agency thereof, nor Battelle Meinorial institute, nor any of their employees, makes any warranty, expressed or implied, or assumes any legal liability or responsibility for the accuracy, completeness, or usefulness of any information, apparatus, product, or process disclosed, or represents that its use would not infringe privately owned rights. Reference herein to any specific commercial product, process, or service by trade name, trademark, manufacturer, or otherwise does not necessarily constitute or imply its endorsement, recommendation, or favoring by the United States Government or any agency thereof, or Battelle Memorial Institute. The views and opinions of authors expressed herein do not necessarily state or reflect those of the United States Government or any agency thereof.

\author{
PACIFIC NORTHWEST LABORATORY \\ operated by \\ BATTELLE MEMORIAL. INSTITUTE \\ for the \\ UNITED STATES DEPARTMENT OF ENERGY \\ under Contract DE-ACO6-76RLO 1830
}

Printed in the United States of America

Available to DOE and DOE contractors from the

Office of Scientific and Technical Information, P.O. Box 62, Oak Ridge, TN 37831; prices available from (685) 576-8401. FTS 626-8401.

Available to the public from the National Tecinical Information Service,

U.S. Department of Commerce, 5285 Port Royal Rd., Springfteld, VA 22161. 
PNL- -8221

DE92. 041232

\title{
RADIONUCLIDE CONCENTRATIONS IN WHITE
} STURGEON FROM THE COLUMBIA RIVER

\author{
D. D. Dauble \\ K. R. Price \\ T. M. Poston
}

September 1992

Prepared for

the U.S. Department of Energy

under Contract DE-ACO6-76RLO 1830

Pacific Northwest Laboratory

Richland, Washington 99352

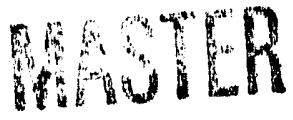




\section{SUMMARY}

Although radioactive releases from the U.S. Depar ment of Energy's Hanford Site have been monitored in the erivironment since the reactors began operating in 1945, recent information regarding historical releases of radionuclides has led to renewed interest in estimating human exposure to radionuclides at Hanford. Knowledge of the fate of radionuclides in some fish species may be important because of the potential for food-chain transfer to humans. White sturgeon (Acipenser transmontanus) were selected for study because they are long-lived, reside year-round in the Hanford Reach, are benthic, and are an important commercial and sport species in the Columbia River. They also have a greater potential for accumulating persistent radionuclides than shorter-lived species with pelagic and/or anadromous life histories.

The purpose of our study was to summarize data on historical concentrations of industrial radionuclides in white sturgeon and to collect additional data on current body burdens in the Columbia River. Historic data on concentrations in white sturgeon were gleaned from a number of reports. Studies conducted from 1953 to 1955 indicated that high concentrations of radionuclides (as total beta) were present in some internal organs and on the external surface of white sturgeon from the Hanford Reach. Average concentrations were about $40 \mathrm{pCi} / \mathrm{g}$ for liver and kidney and exceeded $60 \mathrm{pCi} / \mathrm{g}$ for fins and scutes. The principal radionuclides present in the tissues of white sturgeon collected from the Hanford Reach during 1963 to 1967 were ${ }^{32} \mathrm{P},{ }^{51} \mathrm{Cr}$, and $65 \mathrm{Zn}$. Average concentrations of $32 \mathrm{P}$ in muscle were typically two to seven times greater than $65 \mathrm{Zn}$ and ranged from 25 to $57 \mathrm{pCi} / \mathrm{g}$. When separate tissues were taken from sturgeon, average concentrations of radionuclides were usually in the order gut contents $>$ carcass $>$ muscle. Limited data from locations in the Columbia River downstream of the Hanford Reach in 1953, 1965, and 1966 indicated that low amounts of radionuclides were available for uptake by white sturgeon. Estimated dose contribution from consumption of sturgeon in the mid-1960s was less than the dose estimated from consumption of more commonly harvested fish species (e.g., mountain whitefish).

A field stuciy conducted in 1989 and 1990, as an activity of the Hanford Site Surface Environmental Surveillance Project, showed that radionuclide concentrations in white sturgeon tissue from the Hanford Reach had decreased dramatically since the time of major reactor operation. Maximum concentrations for any measured industrial radionuclide in muscle and cartilage of white sturgeon collected from several locations in the Columbia River were less than $0.01 \mathrm{pCi} / \mathrm{g}$. Principal radionuclides of historical significance $\left({ }^{32} \mathrm{P},{ }^{51} \mathrm{Cr}\right.$, and $\left.{ }^{65} \mathrm{Zn}\right)$ were not detected in these samples. The potential annual dose from Hanford-orgin radionuclides to individuals consuming 
sturgeon muscle in 1991 would be less than 0.01 mrem. Thus, present levels of radionuclides found in edible tissue of white sturgeon pose no risk to human health. 


\section{ACKNOWLEDGMENTS}

Several individuals contributed to the success of this study. C. S. Abernethy, L. E. Eberhardt, R. W. Hanf, Jr., G. A. Martenson, and G. Watters of the Pacific Northwest Laboratory assisted in field collections. G. Seton-Harris helped compile historical data. We also thank A. Setter and E. O. Brannon (University of Idaho), D. Serdar (Washington Department of Ecology), L. LaVoy and J. DeVores (Washington Department of Fisheries), and the Oregon State Police for assistance in obtaining samples. L. E. Eberhardt and C. A. Brandt performed statistical analysis on the recent data. D. G. Watson, R. F. Brich, R. K. Woodruff, and R. L. Dirkes provided useful suggestions on the document, and R. E. Lundgren provided editorial assistance. 


\section{CONTENTS}

SUMMARY Y.............................................................................

ACKNOWLEDGMENTS...................................................... v

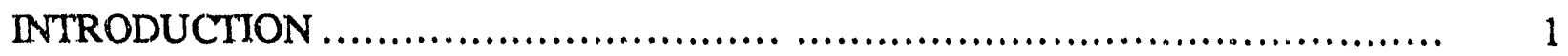

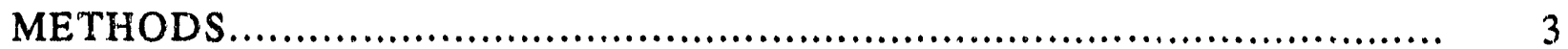

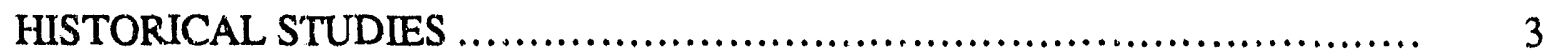

CURRENT STUDIES .................................................... 3

RADIONUCLIDE ANALYSIS.............................................. 6

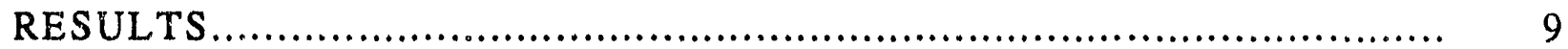

HISTORICAL STUDIES ................................................ 9

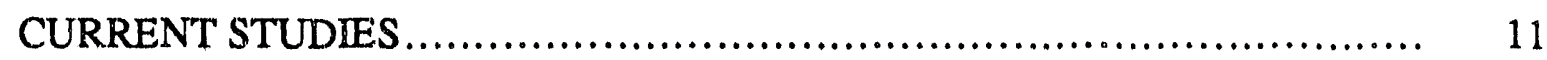

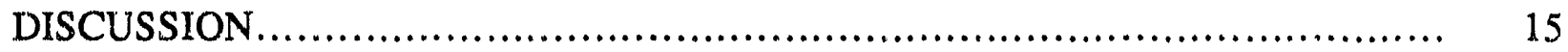

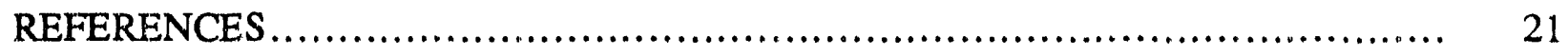

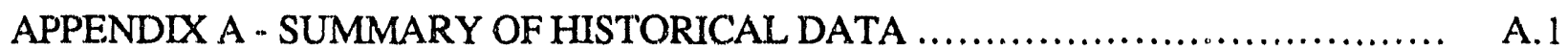

APPENDIX B - DATA FROM CURRENT STUDIES ............................... B. 1 


\section{EIGURES}

1 Relationship of Reactor Operations and Discharge of Radionuclides to the Columbia River, 1944 to 1985

2 Location of Principle Study Sites in the Columbia River Drainage

3 Capture Locations of White Sturgeon Collected in the Hanford Reach and McNary Pool during 1989 and 1990

4 Relative Concentrations of Radionuclides in Sturgeon Tissue in the Hanford Reach, 1953 to 1955

5 Means and Standard Deviations for ${ }^{90} \mathrm{Sr}$ and $137 \mathrm{Cs}$ in White Sturgeon from Three General Locations in the Columbia River.

6 Age-Length Relationship for White Sturgeon Analyzed for Radionuclides in 1989 and 1990

7 Comparison of Radionuclide Concentrations Found in White Sturgeon Muscle during Reactor Operations Versus Present Day

\section{TABLES}

1 General Characteristics of Principal Radionuclides Analyzed for in White Sturgeon Collected during 1989 and 1990

2 Radionuclide Concentrations in Tissue of Two Immature White Sturgeon Collected from the Columbia River near Corbett, Oregon, in 1953

3 Concentrations of Principal Radionuclides in Muscle of White Sturgeon from the Hanford Reach, 1963 to 1967

4 Relative Concentrations of Principal Radionuclides in the Muscle, Carcass, and Gut Contents of White Sturgeon Collected near White Bluffs, Washington, 1966 to 1967

5 Reported Concentrations of Industrial Radionuclides in White Sturgeon Collected from the Lower Columbia River, 1965 and 1966.

6 Range of Concentrations for Radionuclides Found in White Sturgeon Tissue Collected from the Columbia River, 1986 to 1990 


\section{INTRODUCTION}

Environmental monitoring of radioactive releases to the Hanford Reach of the Columbia River has been an important part of operations at the U.S. Department of Energy's Hanford Site since the first plutonium production reactor began discharging radionuclides into the Columbia River via conling waters in 1944. The greatest releases of radioactive materials to the Columbia River occurred during the eariy to mid-1960s when the largest number of once-through-cooled production reactors were in operation. The largest amount of radioactive effluents discharged to the Columbia River occurred between 1959 and 1965 and correlated with the number of reactors operating (Figure 1). During this interval, concentrations of certain radionuclides were routinely monitored in algae, invertebrates, and fish. The majority of this information was summarized in special reports, including Davis et al. (1956), Watson et al. (1970), and annual reports to the U.S. Department of Energy (Foster et al. 1962, 1963, 1964, 1965).

Direct discharge of once-through-cooling water to the Hanford Reach from reactors ended in 1971 with closure of the KE Reactor. Following shutdown of the reactors, Cushing et al. (1980) measured the decline of the body burdens of radionuclides in various biota of the Columbia River ecosystern. These studies indicated that body burdens of industrial radionuclides decreased to undetectable levels in most aquatic biota by 1973 . This decline was attributed to three processes: 1) physical decay of the radionuclides, 2) biological turnover of the element by the organisms, and, 3) decreasing biological availability of radionuclides in the environment. By 1989, all plutonium production activities at Hanford had ceased and $\mathrm{N}$ Reactor, the only remaining production reactor, was placed on cold standby status.

Knowiedge of present radionuclide concentrations in aquatic biota is important because of a renewed interest in estimating human exposure to current and historical releases of radionuclides during Hanford operations. Knowledge of the fate of radionuclides in fish may be important because of the potential for food-chain transfer to humans. White sturgeon (Acipenser transmontanus) are a long-lived fish species [individuals estimated at $>25$ years old have been collected in the Hanford Reach during various studies (Haynes et al. 1978; Page et. al. 1976)]. Sturgeon reside year-round in the Hanford Reach and can take up radionuclides directly from the water, from ingestion of contaminated sediments, and through the aquatic food chain (Dauble et al. 1988). In addition, benthic fish species, like white sturgeon, can be expected to accumulate higher levels of sediment-sorbed radionuclides than fish with pelagic life styles (Poston and Klopfer 1986). Because dams represent a barrier to upstream movement of white sturgeon (Haynes et al. 


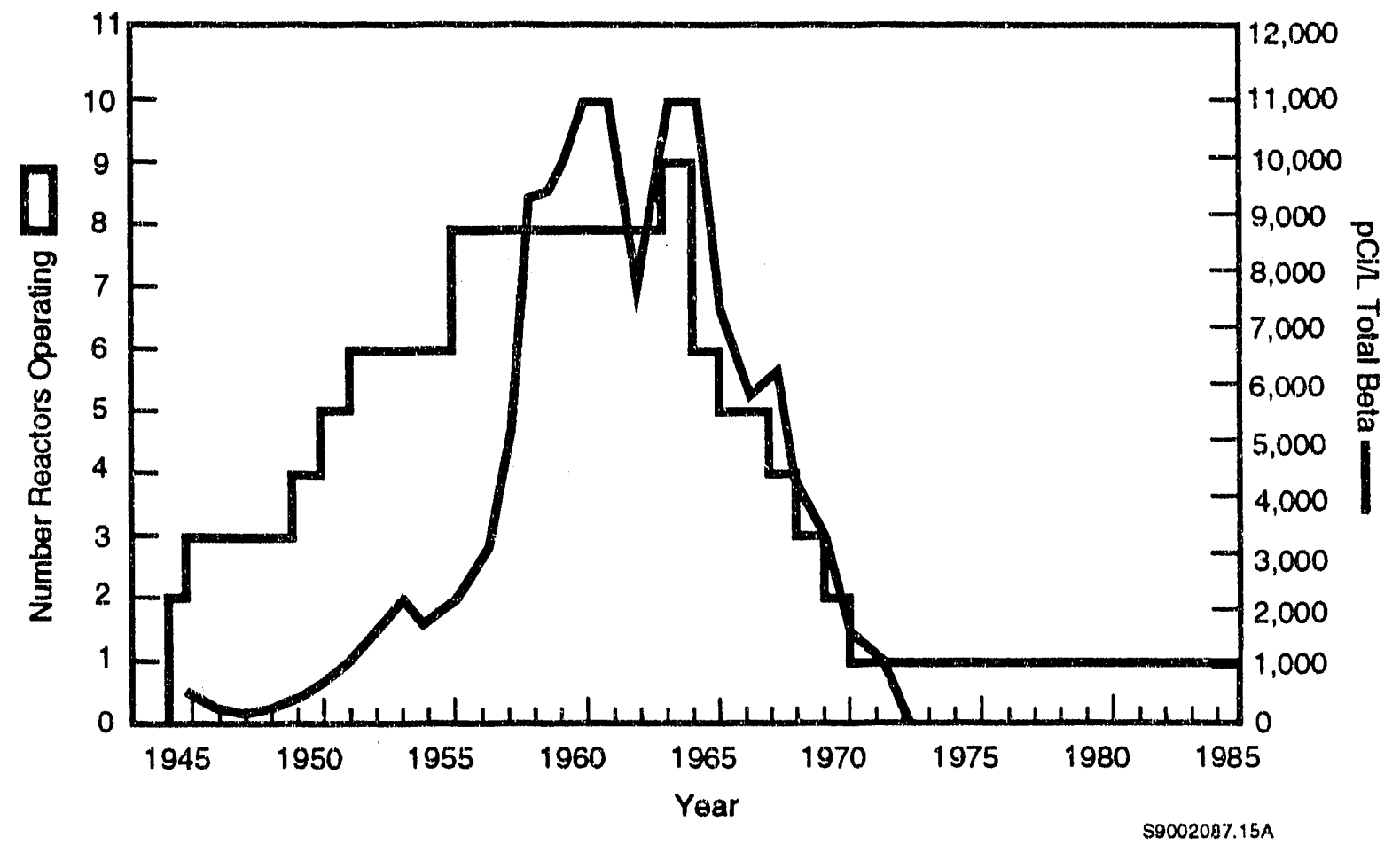

FIGURE1. Relationship of Reactor Operations and Discharge of Radionuclides to the Columbia River, 1944 to 1985

1978), fish collected from the Hanford Reach have been restricted to the Hanford Reach or the area bounded by Priest Rapids Dam and McNary Dam in the Columbia River, and by Ice Harbor Dam on the Snake River since 1961. Other fish species common to the Hanford Reach are shorter-lived than white sturgeon and/or migrate out of the Hanford Reach during their life span.

The objectives of our study were to 1) review and summarize historical data on radionuclide concentrations in white sturgeon from the Columbia River, 2) determine present-day radionuclide tissue burdens from different locations in the Columbia River, and 3) compare historical data with current data. We first reviewed and summarized the historical literature on radionuclide concentrations in white sturgeon from the Hanford Reach. Field studies were then conducted to evaluate the relationship among sample locations, age/length of white sturgeon, and present radionuclide tissue burdens. Results and comparisons are discussed in the remainder of this report. 


\section{METHODS}

Different methods were employed by the historical studies and those conducted more recently. The historical studies also analyzed different tissues and different radionuclides than the recent studies. These differences are noted below.

\section{HISTORICAL STUDIES}

The earliest known record of radionuclide analysis in white sturgeon was from Davis et al. (1956) who summarized limited data on the relative distribution of radioactivity (measured as gross beta) in tissues of white sturgeon collected from 1953 to 1955. Most of the collection and analysis of sturgeon samples occurred from 1961 to 1972 (Bramson and Corley 1973; Corley and staff 1969; Foster and staff 1962, 1963, 1964, 1965, 1966; Honstead and staff 1967; Watson et al. 1970). During that interval, white sturgeon were collected by various methods from McNary to Priest Rapids Dams. Some samples were categorized as "small fish" or "large fish," but no lengths or ages were provided. General locations of capture were usually reported. Typically, the gut contents were removed, a sample from the anterior gut was retained for radioanalysis, and the fish was separated into muscle and carcass (i.e., remainder) fractions that were ground into a homogenate (Watson et al. 1970). We report values taken from summary tables in reports to the U.S. Department of Energy. These values include data from both individual samples and/or group means (Appendix A).

\section{CURRENT STUDIES}

In the more recent study, collections were restricted to legal-sized fish, (i.e., approximately 90 to $180 \mathrm{~cm}$ total length), depending on sport fishing regulations in a study area. Additional samples outside this size range were from confiscated fish provided by law enforcement and management agencies. White sturgeon were collected in three primary study areas and also near The Dalles, Oregon (Figure 2). The main area of interest included the Hanford Reach and the McNary pool. Specific capture locations of fish from this area are shown in Figure 3. Fish collected in Lake Roosevelt were considered to be a reference control population (i.e., any radionuclide source would include natural sources and worldwide fallout from weapons testing). Fish collected from locations downstream of McNary Dam contained radionuclides from natural sources, worldwide fallout, and radionuclides transported downstream from Hanford. 


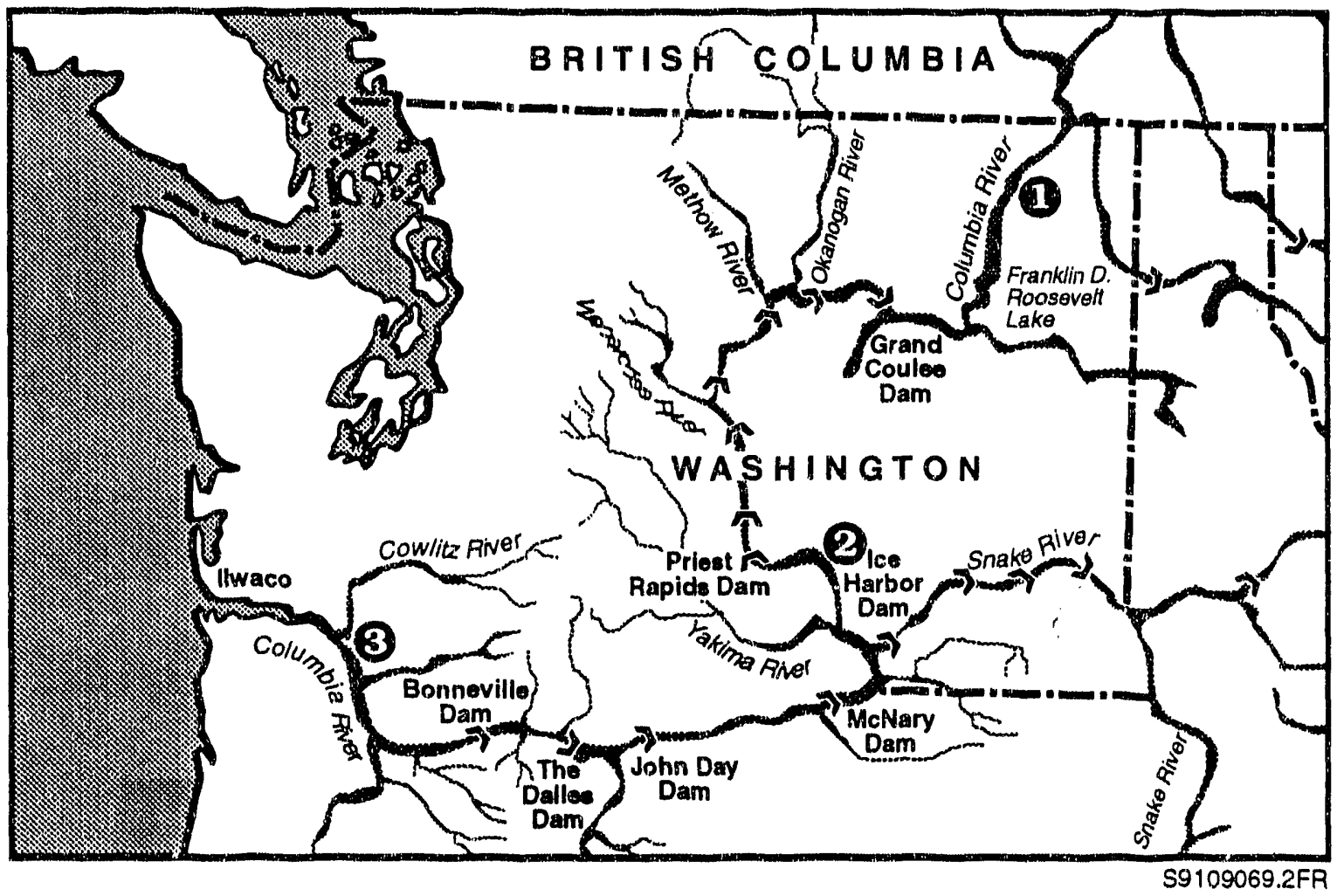

FIGURE 2. Location of Principal Study Sites in the Columbia River Drainage. Key: 1 = near Lake Roosevelt ; 2 = Hanford Reach including McNary pool; 3 = lower Columbia River below Bonneville Dam.

Fish were collected with set-lines from September 1989 to Octobe 1990 . Where possible, efforts were coordinated with studies conducted by the Washington Department of Fisheries, Washington Department of Ecology, and University of Idaho. A volunteer program was initiated with sport fishers in the Hanford Reach and the lower Columbia River near Chinook, Washington. This resulted in the donation of several carcasses for radionuclide analysis. Additional samples were purchased from commercial fish buyers at Ilwaco, Washington. The Oregon State Police provided samples from four oversize sturgeon $(>183 \mathrm{~cm})$ that were confiscated from illegal fishing activities near The Dalles Dam.

When possible, total length, weight, capture date and location, sex, and degree of maturity were recorded for each fish. Age analysis was conducted using sections taken from pectoral fins as described in Hess (1984). After initial data collection in the field, fish were eviscerated, skinned, and prepared for laboratory analysis. Tissues analyzed consisted of skinless muscle fillets, liver minus gallbladder, and head cartilage. All samples were rinsed with distilled water, sealed in plastic bags, and frozen for up to 12 months before analysis. 


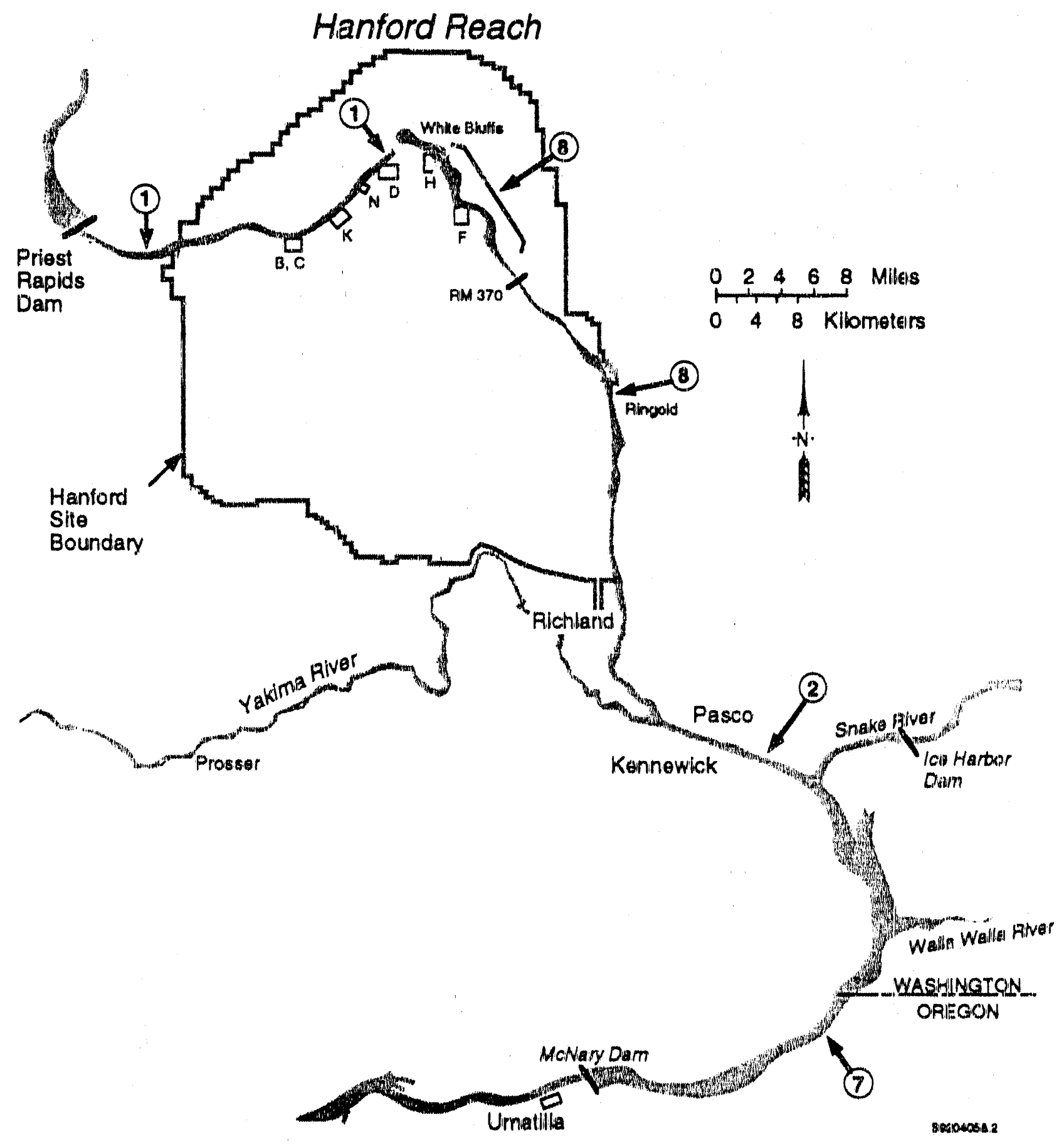

FIGURE3. Capture Locations of White Sturgeon Collected in the Hanford Reach and the McNary Pool during 1989 and 1990. Relative sample size for each general location is circled. 


\section{RADIONUCLIDEANALYSIS}

Historical samples were usually analyzed for total beta emitters and gamma-emitting radionuclides. Concentrations were reported as $\mathrm{pCi} / \mathrm{g}$ wet weight. Gross beta was determined with a gas-flow proportional analyzer, and ${ }^{32} \mathrm{P}$ was determined by using aluminum absorbers of differing thicknesses. Gamma radiation was measured with an NaI well crystal with readout on a 400-channel analyzer. Measurements were usually made of the following radionuclides: ${ }^{24} \mathrm{Na}$,

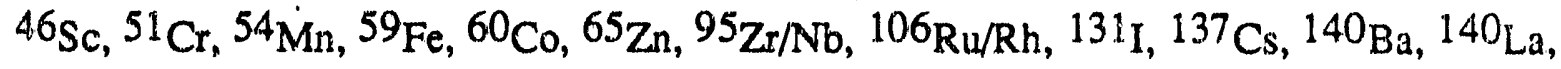
${ }^{144} \mathrm{Cr} / \mathrm{Pr}$, and ${ }^{239} \mathrm{~Np}$ (Watson et al. 1970).

Selection of radionuclides for analysis in 1989 and 1990 was based on the following criteria: 1) relatively long physical half-life, 2) low biological turnover rate, and/or 3) known presence in the environment (Table 1). For ${ }^{90} \mathrm{Sr}$ analysis, cartilage samples were oven-dried, ashed in a furnace, treated with nitric acid, and precipitated with fuming nitric acid. Strontium-90 was then scavenged with barium chromate, precipitated as a carbonate, and cransferred to a stainless steel planchet before counting with a gas-flow proportional counter. Gamma-emitting radionuclides (i.e., ${ }^{40} \mathrm{~K},{ }^{60} \mathrm{Co},{ }^{65} \mathrm{Zn}$, and ${ }^{137} \mathrm{Cs}$ ) were counted directly on dried muscle samples using a $\mathrm{Ge}(\mathrm{Li})$ detector with a multichannel, pulse-height analyzer. Data from a suite of additional gamma-emitting radionuclides were reviewed for completeness; however, most were below detection limits and were not reported. These radionuclides included $40_{\mathrm{K}},{ }^{65} \mathrm{Zn},{ }^{9} \mathrm{Zr}-\mathrm{Nb}$, ${ }^{134} \mathrm{Cs}, 103,106 \mathrm{Ru},{ }^{125} \mathrm{Sb},{ }^{144} \mathrm{Ce}-\mathrm{Pr}, 154,155_{\mathrm{Eu}}, 212,214 \mathrm{~Pb}$, and ${ }^{226} \mathrm{Ra}$. Generally, the operational detection limit for these radionuclides ranged from 0.02 to $0.3 \mathrm{pCi} / \mathrm{g}$ dry weight. Liver samples were analyzed for plutonium (238 $\mathrm{Pu}, 239 / 240 \mathrm{Pu}$ ) following nitric acid digestion, chemical separation, - -d extraction into ether. The plutonium was then plated out onto stainless steel discs and counted on an alpha spectrophotometer. In all cases, results were obtained from individual fish samples. The associated error for measurable values generally ranged from $10 \%$ to $70 \%$, and the larger error occurred with concentrations nearer the detection limit. 
TABLE 1. General Characteristics of Principal Radionuclides Analyzed for in White Sturgeon Collected during 1989 and 1990

Physical

\begin{tabular}{|c|c|}
\hline Radionuclide & Half.life(a) \\
\hline $40_{K}^{(d)}$ & $1.28 \times 10^{9} \mathrm{yr}$ \\
\hline${ }^{54} \mathrm{Mn}$ & $303 \mathrm{~d}$ \\
\hline${ }^{60} \mathrm{Co}$ & $5.3 \mathrm{yr}$ \\
\hline $65 \mathrm{Zn}$ & $245 d$ \\
\hline${ }^{90} \mathrm{Sr}$ & $28.1 \mathrm{yr}$ \\
\hline${ }^{137} \mathrm{Cs}$ & $30.2 \mathrm{yr}$ \\
\hline${ }^{238} \mathrm{Pu}$ & $86 \mathrm{yr}$ \\
\hline $239 / 240 \mathrm{Pu}$ & $24,400 \mathrm{yr}$ \\
\hline
\end{tabular}

Biological Half-Time

\begin{tabular}{llll}
\hline Mammals $(b)$ & & Fish(c) & Emirter \\
\cline { 4 - 4 } no data & no data & gamma \\
no data & $200 \mathrm{~d}$ & gamma \\
$63 \mathrm{~d}$ & $31-63 \mathrm{~d}$ & gamma \\
$177 \mathrm{~d}$ & $138 \mathrm{~d}$ & gamma \\
$2 \mathrm{yr}$ & $138 \mathrm{~d}$ & beta \\
$600 \mathrm{~d}$ & $100-200 \mathrm{~d}$ & gamma \\
$>40 \mathrm{yr}$ & $9-1414 \mathrm{~d}$ & alpha \\
no data & no data & alpha
\end{tabular}
(a) From CRC (1983).
(b) Based on maximum values reported for target tissues in mammals (Napier et al. 1988).
(c) From Coughtrey and Thome (1983) and Gamez et al. (1991).
(d) $40 \mathrm{~K}$ is a naturally occurring radionuclide. 


\section{RESURTS}

Results of historical studies conducted in the Hanford Reach from 1953 to 1972 were taken from published reports. Additional data are presented for sturgeon collected in the lower Columbia and Williamette rivers in 1953, 1965, and 1966. Results from the post-reactor operations interval include data from fish collected from 1986 to 1990 at several locations in the Columbia River. We provide a summary of those results in this section of the report. More detailed data are contained in Appendix A (1961 to 1967 interval) and Appendix B (1986 to 1990 interval).

\section{HISTORICAL STUDIES}

Studies conducted from 1953 to 1955 indicated that elevated concentrations of radionuclides (as gross beta) were present in some internal organs and on the external surface of white sturgeon collected from the Hanford Reach (Figure 4; Davis et al. 1956). These studies occurred before peak reactor operation and provide the only known data on relative concentrations among various tissues. Average concentrations were about $40 \mathrm{pCi} / \mathrm{g}$ for the liver and kidney and exceeded $60 \mathrm{pCi} / \mathrm{g}$ for the fins and scutes.

Limited collections of white sturgeon from a location about 200 miles downstream of the Hanford Reach in 1953 indicated that low concentrations of radionuclides (as gross beta) were present in muscle and on the external surface (Table 2). However, slightly higher concentrations of radionuclides were found in the liver and digestive tract.

The principal radionuclides present in the tissues of white sturgeon collected from several locations in the Hanford Reach and McNary pool during 1963 to 1967 were ${ }^{32} \mathrm{P},{ }^{51} \mathrm{Cr}$, and $65 \mathrm{Zn}$ (Table 3). Concentrations of individual radionuclides in muscle ranged from $<0.01$ to $25.3 \mathrm{pCi} / \mathrm{g}$. Physical half-lives for the principal radionuclides found in sturgeon tissue are short, ranging from 14.3 days for ${ }^{32} \mathrm{P}$ to 245 days for ${ }^{65} \mathrm{Zn}$. Concentrations of $32 \mathrm{P}$ in fish muscle were about six times those of the next highest radionuclide $(65 \mathrm{Zn})$.

Relative concentrations of radionuclides were also measured in the muscle, carcass, and gut contents of white sturgeon collected near White Bluffs (Columbia River mile 370) during 1960 to 1967. Concentrations of $32 \mathrm{P}, 51 \mathrm{Cr}$, and $65 \mathrm{Zn}$ in the carcass were similar and ranged from about 32 to $40 \mathrm{pCi} / \mathrm{g}$. However, ${ }^{51} \mathrm{Cr}$ concentrations in gut contents were two to thres times higher than those measured for $65 \mathrm{Zn}$ and $32 \mathrm{P}$, respectively. Other radionuclides, includinf; ${ }^{46} \mathrm{Sc},{ }^{54} \mathrm{Mn}$, and ${ }^{59} \mathrm{Fe}$, were found at relatively high concentrations $(>70 \mathrm{pCi} . \mathrm{g}$ ) in the gut contents, but were found 


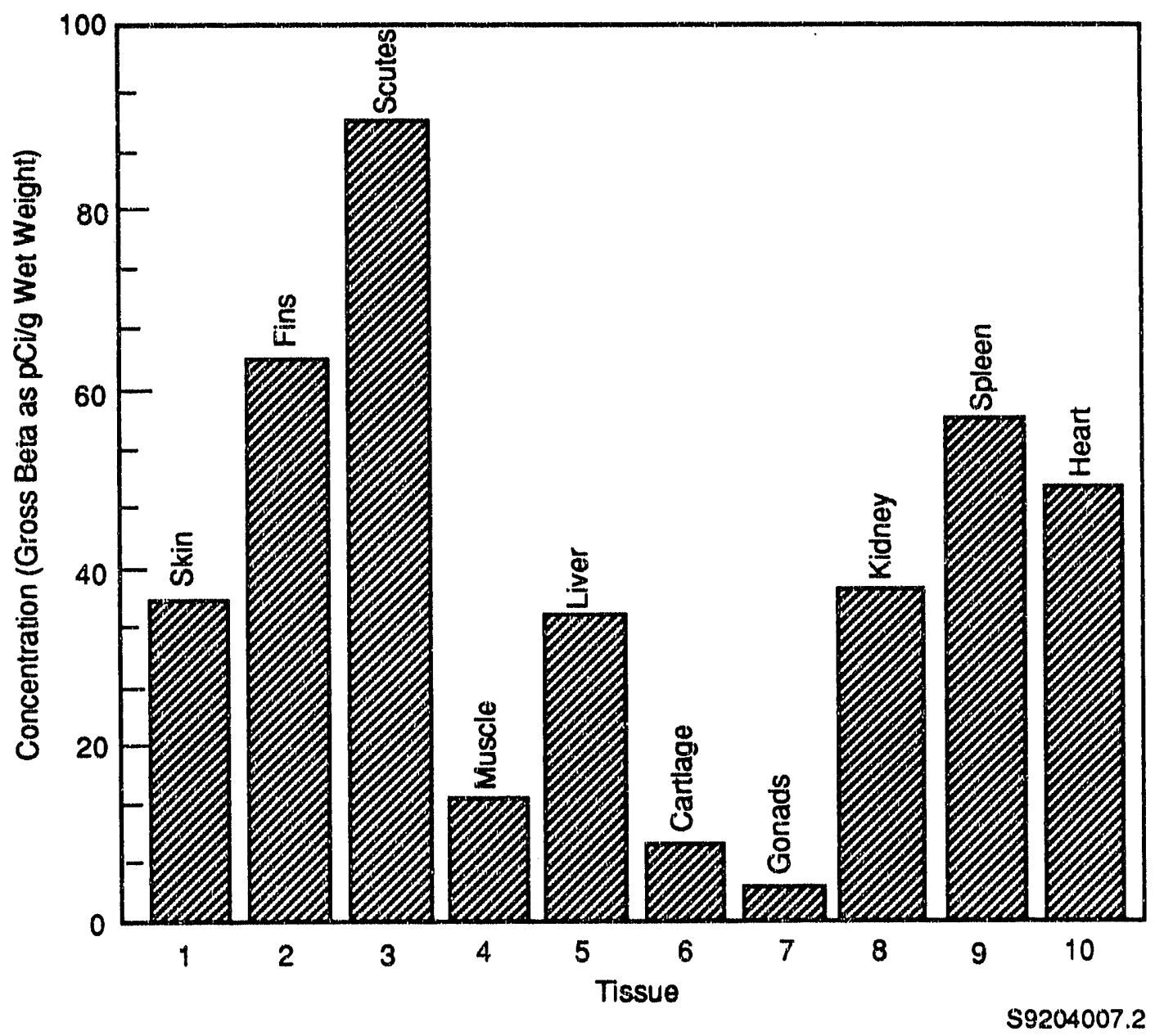

EIGURE 4. Relative Concentrations of Radionuclides (as gross beta) in Sturgeon Tissue in the Hanford Reach, 1953 to 1955 (from Davis et al. 1956)

TABLE 2. Radionuclide Concentrations (as gross beta) in Tissue of Two Immature White Sturgeon ( 460 and $485 \mathrm{~mm}$ total length) Collected from the Columbia River near Corbett, Oregon, in 1953 (from Robeck et al. 1954). Negative values represent concentrations below detection limits.

Radionuclide Concentration $\mathrm{DC} / \mathrm{g}$

Sample Skin Muscle Scutes Notochord Ovary Liver with gut contents

Fish $1 \quad-0.6$

$0.8 \quad 4.1$

0.3

9.1

41.0

Fish 2

10.0

$-0.1$

2.0

2.3

4.6

6.2

4.3 
TABLE 3. Concentrations ( $\mathrm{pCi} / \mathrm{g}$ ) of Principal Radionuclides in Muscle of White Sturgeon from the Hanford Reach (several locations combined), 1963 to 1967 (see Appendix A.1)

\begin{tabular}{|c|c|c|c|c|}
\hline Radionuclide & Sample Size & Mean & Min & $\operatorname{Max}$ \\
\hline $32 \mathrm{P}$ & 88 & 25.3 & 2 & 230 \\
\hline $40 \mathrm{~K}$ & 68 & 3.8 & 2 & 40 \\
\hline $46 \mathrm{sc}$ & 13 & $<0.1$ & 0 & 0.2 \\
\hline $51 \mathrm{Cr}$ & 17 & 5.2 & 0 & 15 \\
\hline $54 \mathrm{Mn}$ & 13 & 0.1 & 0 & 0.3 \\
\hline $58 \mathrm{Co}$ & 11 & 2.2 & 0.2 & 20 \\
\hline${ }^{59} \mathrm{Fe}$ & 12 & 0.1 & 0 & 0.4 \\
\hline${ }^{60} \mathrm{Co}$ & 21 & 0.4 & 0 & 3 \\
\hline $65 \mathrm{Zn}$ & 88 & 12.3 & 0.3 & 62 \\
\hline $137 \mathrm{Cs}$ & 49 & 0.5 & 0 & 1 \\
\hline
\end{tabular}

at very low concentrations $(<0.2 \mathrm{pCi} / \mathrm{g})$ in the muscle and carcass (Table 4$)$. With the exception of ${ }^{32} \mathrm{P}$ and ${ }^{137} \mathrm{Cs}$, the average relative concentration of radionuclides was gut contents $>$ carcass $>$ muscle.

Ccincentrations of radionuclides in samples of four white sturgeon collected from the lower Columbia and Williamette rivers were significantly lower than those found in samples from the Hanford Reach during 1965 and 1966 (Table 5). In 1966, concentrations of $65 \mathrm{Zn}$ in muscle of white sturgeon from the lower Columbia River were about $17 \%$ of those form sturgeon collected in the Hanford Reach. The concentrations of other radionuclides analyzed for were below detection limits.

\section{CURRENT STUDIES}

The range in measured concentrations of radionuclides in the muscle and cartilage of white sturgeon collected from various sites in the Columbia River is shown in Table 6. No other industrial radionuclides, including gamma emmiters (in muscle tissue) and plutonium ( $238 \mathrm{Pu}$, $239 / 240 \mathrm{Pu}$ ) in liver, were found at levels exceeding the detection limits. Results of all measurements are in Appendix B. 
TABLE4. Relative Concentrations of Principal Radionuclides in the Muscle, Carcass, and Gut Contents of White Sturgeon Collected near White Bluffs, Washington (Columbia River mile 370), 1966 to 1967. Sample sizes ranged from 32 to 41 fish (see Appendix A.2).

\section{Relative Concentrations, average $\mathrm{pCi} / \mathrm{g}$ wet weight}

\begin{tabular}{cccc} 
Radionuclide & Muscle & Carcass & Gutcontents \\
\hline $32 \mathrm{P}$ & 56.7 & 39.7 & 317.2 \\
$46 \mathrm{Sc}$ & $<0.1$ & 0.7 & 112.8 \\
$51_{\mathrm{Cr}}$ & 2.8 & 32.1 & 1108.0 \\
$54^{\mathrm{Mn}}$ & 0.2 & 0.4 & 72.6 \\
$59_{\mathrm{Fe}}$ & 0.1 & 0.7 & 120.3 \\
$60 \mathrm{Co}$ & $<0.1$ & 0.5 & 2.0 \\
$65_{\mathrm{Zn}}$ & 8.9 & 33.5 & 526.7 \\
$137 \mathrm{Cs}$ & 0.6 & 0.2 & 3.3
\end{tabular}

TABLE 5. Reported Concentrations of Industrial Radionuclides in White Sturgeon Collected from the Lower Columbia River, 1965 and 1966 (from Toombs and Cutler 1968)

\begin{tabular}{|c|c|c|c|c|c|}
\hline \multirow[b]{2}{*}{ Location } & \multirow[b]{2}{*}{ Tissue } & \multicolumn{4}{|c|}{ Radionuclide $\mathrm{pCi} / \mathrm{g}$ wet weight } \\
\hline & & $51 \mathrm{Cr}$ & $65 \mathrm{Zn}$ & $95 \mathrm{Nb}$ & $103 \mathrm{Ru}$ \\
\hline $\begin{array}{l}\text { Williamette River } \\
\text { (Oregon City) }\end{array}$ & Whole Body & - & 0.1 & - & - \\
\hline \multirow{3}{*}{$\begin{array}{l}\text { Columbia River } \\
\text { (river mile 28) }\end{array}$} & Muscle & $<0.01$ & 1.6 & $<0.01$ & $<0.01$ \\
\hline & Muscle & - & 1.8 & $<0.01$ & $<0.01$ \\
\hline & Muscle & - & 1.0 & $<0.01$ & $<0.01$ \\
\hline
\end{tabular}

Sampling locations were combined as three groups relative to the Hanford Reach for statistical analysis. Thus, sturgeon taken from Lake Roosevelt were designated as "upstream" and sturgeon from near The Dalles Dam and below Bonneville Dam were combined as "downstream." This combination of sampling locations provided a more even distribution of sizes/ages among groups than the four-group combination that included fish from The Dalles Dam as a separate group. A one-way analysis of variance (ANOVA) of log-transformed values indicated that concentrations of both ${ }^{137} \mathrm{Cs}$ (muscle) and ${ }^{90} \mathrm{Sr}$ (cartilage) were not significantly different among the three study areas ( $\mathrm{P}>0.3$ and $>0.8$, respectively). Mean concentrations of ${ }^{90} \mathrm{Sr}$ and $137 \mathrm{Cs}$ in sturgeon tissue and standard deviations about the mean are shown in Figure 5. There were 
TABLE 6. Range of Concentrations ( $\mathrm{pCi} / \mathrm{g}$ wet weight) for Radionuclides Found in White Sturgeon Tissue Collected from the Columbia River, 1986 to 1990. (Negative values indicate concentrations below detection limits).

\begin{tabular}{|c|c|c|c|c|c|}
\hline \multirow[b]{2}{*}{ Location } & \multirow{2}{*}{$\begin{array}{c}\text { Sample } \\
\text { Size }\end{array}$} & \multicolumn{3}{|c|}{ Muscle } & \multirow{2}{*}{$\begin{array}{c}\text { Cartilage } \\
90 \mathrm{Sr} \\
\end{array}$} \\
\hline & & ${ }^{137} \mathrm{Cs}$ & ${ }^{60} \mathrm{Co}$ & $40 \mathrm{~K}$ & \\
\hline sevelt & 9 & $0.008-0.032$ & $-0.093-0.076$ & $2.86-3.67$ & $0.004-0.03 ?$ \\
\hline anford Reach & 27 & -0.001 & $-0.011-0.071$ & $1.33-7.48$ & $<0.001-0.065$ \\
\hline he I & 4 & 35 & $<0.001-0.054$ & $3.45-4.28$ & $<0.001-0.067$ \\
\hline Below & 14 & $<0.001-0.019$ & $<0.001-0.014$ & $1.60-4.04$ & -0.001 \\
\hline
\end{tabular}

insufficient values of ${ }^{60} \mathrm{Co}$ to conduct statistical analysis. Concentrations of $40 \mathrm{~K}$, a naturally occurring radionuclide, were also determined for white sturgeon muscle. These values would not be expected to change over time, and any differences are probably indicative of variability associated with analysis of environmental samples at low concentrations.

Based on all 52 fish collected from the Columbia River for which ages were determined, there was a clear relationship between age of white sturgeon and total length $\left(R^{2}=0.42\right.$;

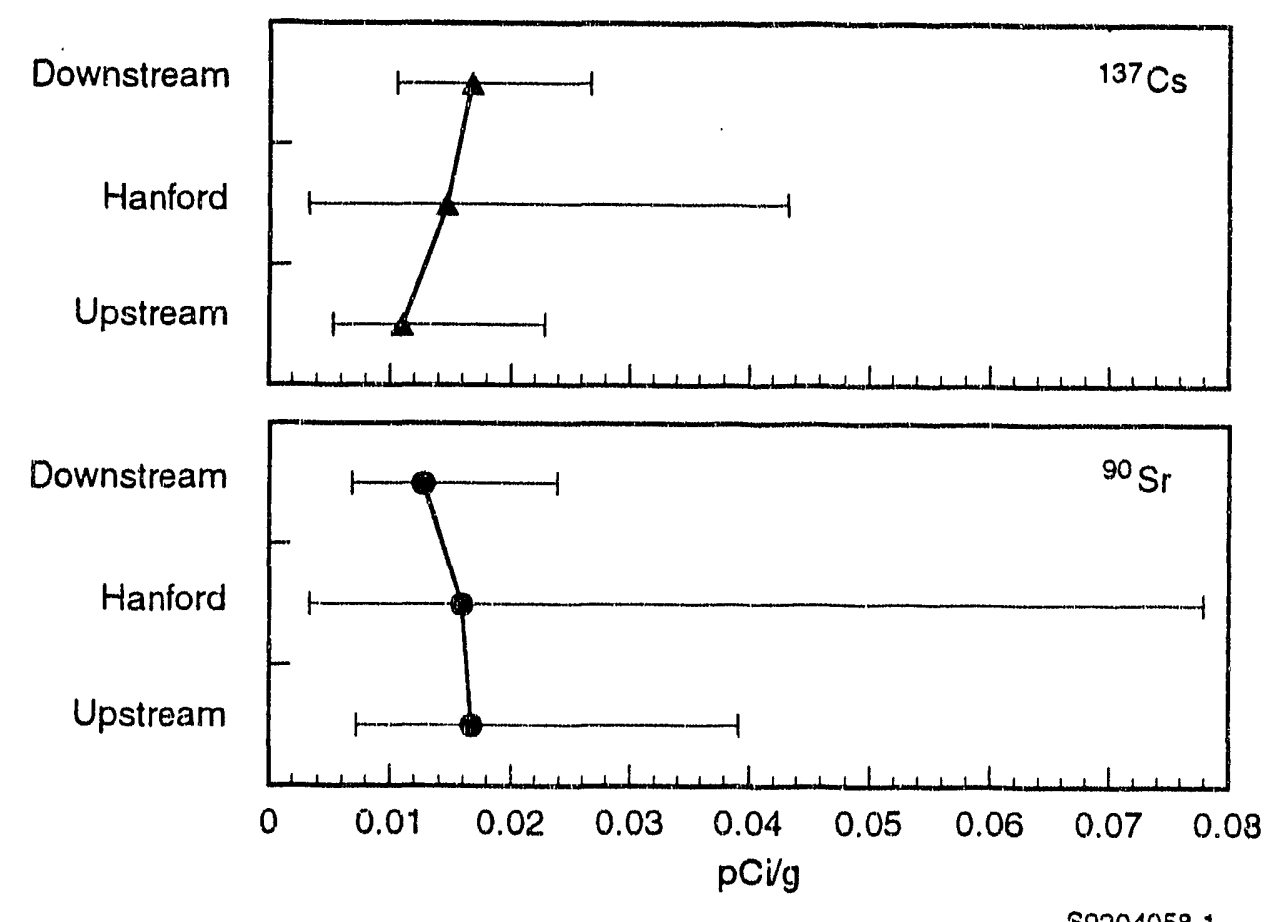

EIGURE 5. Means and Standard Deviations for $90 \mathrm{Sr}$ and ${ }^{137} \mathrm{Cs}$ in White Sturgeon from Three General Locations in the Columbia River 
$P=0.0001$; Figure 6). However, there was no relationship between concentrations of either ${ }^{137} \mathrm{Cs}$ in the muscle or ${ }^{90} \mathrm{Sr}$ in the cartilage and the age of sturgeon $(\mathrm{P}=0.32$ and 0.83 , respectively), or the length of sturgeon ( $P=0.77$ and 0.93 , respectively).

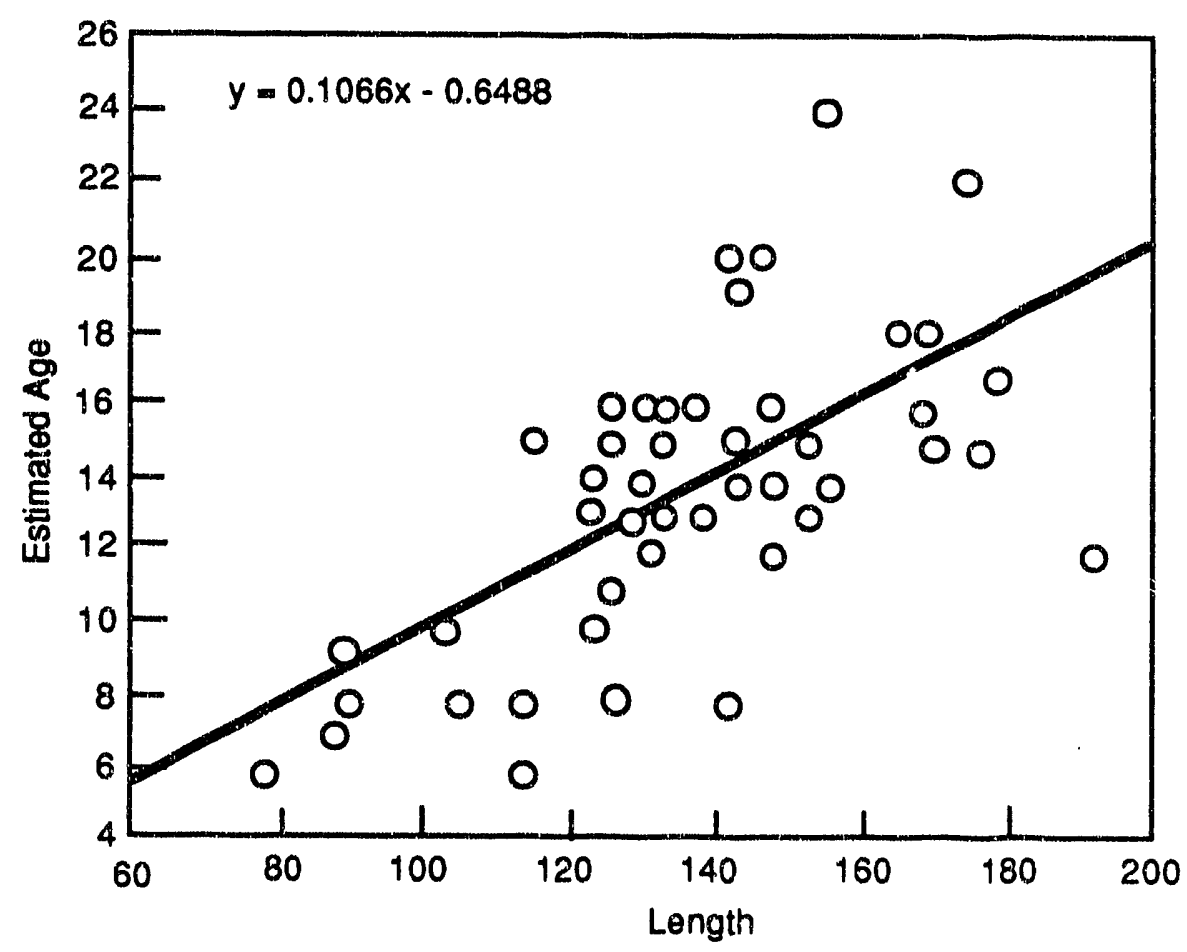

59204058.1

FIGURE 6. Age-Length Relationship for White Sturgeon Analyzed for Radionuclides in 1989 and 1990 


\section{DISCUSSION}

Availability of radionuclides to aquatic biota is related to the relative concentrations or chemical characteristics of radionuclides that were discharged, siver flows (dilution and transport), sediment load, and distance downstream from the reactors (Hauschild et al. 1971, 1975; Perkins et al. 1966). The use of Columbia River water to cool nuclear production reactors and subsequent discharge of the cooling water back into the river introduced radioactive elements into the river environment from 1944 to 1971 . During that interval, most radionuclides were produced after neutron activation of stable elements in the cooling water and the sloughing off of radioactive corrosion products from the reactor cooling tubes. Radionuclides of greatest biological importance during early studies on aquatic biota were ${ }^{32} \mathrm{P}$ and ${ }^{65} \mathrm{Zn}$ (Watson et al. 1970). Historical data clearly show that these two radionuclides and ${ }^{51} \mathrm{Cr}$ were readily taken up by white sturgeon during the years of peak reactor operation. During the 1960s, concentrations of radionuclides in the gut contents were about 10 to 500 times those found in the carcass and muscle of white sturgeon. This suggests that transfer of most radionuclides across the digestive tract to muscle tissue was inefficient or that elimination mechanisms were effective in removing most of the radionuclides taken up via the gut.

Both dissolved and particle-bound radionuclides from past Hanford operations were eventually transported downstream. The longer-lived radionuclides (e.g. ${ }^{60} \mathrm{Co},{ }^{90} \mathrm{Sr},{ }^{137} \mathrm{Cs},{ }^{241} \mathrm{Am}$, and $239,240 \mathrm{Pu}$ ) were distributed in the streambed from the reactors to the Pacific Ocean mainly as a result of adsorption to and transport by sediment. In $1965,40 \%$ of the radionuclide accumulation in sediments was in McNary Dam reservoir and $52 \%$ was in sediments deposited below The Dalles Dam (Hauschild et al. 1975). Subsequently, Beasley et al. (1981) reported that $20 \%$ to $25 \%$ of the total plutonium behind McNary Dam was of Hanford origin; the remainder arose from global fallout resulting from aboveground weapons testing in the 1950s and 1960s. Additional studies on McNary sediment cores removed in 1977 and 1978 indicated that although inventories of $60 \mathrm{Co}$ could be attributed to the operation of production reactors at Hanford, sediment inventories of ${ }^{137} \mathrm{Cs},{ }^{241} \mathrm{Am}$, and $239,240 \mathrm{Pu}$ were derived primarily from global fallout.

White sturgeon are primarily bottom feeders (Semakula and Larkin 1968) and can take up radionuclides directly from the water, by ingesting contaminated sediments, or via the aquatic food chain. Each of these routes of uptake is likely to have contributed to body burdens during reactor operation. Since 1972, however, concentrations of radionuclides in the water and aquatic biota decreased to nearly undetectable levels (Cushing et al. 1980). 
Contaminated sediments in the pools behind McNary and downstream dams have become less available to sturgeon and other aquatic biota as materials deposited from 1944 to 1971 were covered with layers of uncontaminated sediments. Input of radionuclides to the bed sediments has been minimal after cessation of single-pass reactor operations in the Hanford Reach and following the ban on atmospheric testing of nuclear weapons. Robertson and Fix (1977) determined that, during 1971 to 1976, up to $80 \mathrm{~cm}$ of "clean" sediment had covered contaminated sedin tents deposited when production reactors had discharged radioactivity into the Columbia River. Additionally, based on physical decay alone and assuming no new inputs, ${ }^{60} \mathrm{Co}$ and ${ }^{137} \mathrm{Cs}$ inventories would be reduced to $0.1 \%$ of their 1977-1978 values in just over 50 and 300 years, respectively (Beasley and Jennings 1984).

The only sources of radionuclides in the Hanford Reach since the last once-through-cooled reactor was shut down in 1971 are the recycling of radionuclides sorbed on river sediments, indirect releases from the $\mathrm{N}$ Reactor (up through 1985), or radionuclides migrating from waste sites through the groundwater and into the river. For example, ${ }^{60} \mathrm{Co}$ and ${ }^{90} \mathrm{Sr}$ migrate through the ground from a disposal site near $\mathrm{N}$ Reactor and are readily available for biological uptake by aquatic biota when seep water from springs enters the Columbia River (Cushing et al. 1988). However, concentrations of $60 \mathrm{Co}$ and ${ }^{90} \mathrm{Sr}$ at Hanford Reach sturgeon were not significantly different from those in sturgeon collected at either upstream or downstream reference locations. Thus, radionuclides that are present today and attributable to past Hanford operations are not bioaccumulated by white sturgeon. Mean values of radionuclides in sturgeon tissue are very low and may be considered "background" levels.

Because of radioactive decay and reduced discharge to the river, radionuclides are present today at markedly lower levels than historical levels. Our samples included sturgeon that were present in the Columbia River from about 1966 to 1985 . However, most of the fish we collected in 1989 and 1990 were around 15 years old and thus present in the river since about 1976. Only low levels of radionuclides were present for uptake by aquatic biota during this interval (Cushing et al. 1980). Thus, it is not surprising that concentrations of radionuclides in white sturgeon tissues were quite low in our recent study.

We looked for plutonium in the liver of white sturgeon because of its toxicity and persistence in the aquatic environment, but were unable to detect either $238 \mathrm{Pu}$ or $239,240 \mathrm{Pu}$ in any samples. A major factor reducing uptake of plutonium by aquatic biota is the tendency to be sorbed by sediments. Most studies of plutonium in freshwater systems indicate that the sediments contain greater than $99 \%$ of the total plutonium inventory (reviewed in Emery et al. 1978). Because of expected low concentrations in the environment and because plutonium bound to sediments are not bioavailable, it is unlikely that detectable amounts of plutonium would be found 
in fish tissue. For example, Emery et al. (1978) reported that goldfish (Carassus auratus) in a heavily contaminated former waste-water pond at Hanford contained less than $0.001 \%$ of the plutonium estimated to be in the entire pond.

An important aspect of the study was to determine if a relationship existed between radionuclide concentrations and age/size of captured fish. Bosley and Gately (1981) previously reported that residue levels of a persistent organochlorine compound generally increased in direct proportion to age of white sturgeon from the Columbia River. Thus, white sturgeon might be expected to show increased tissue burdens of persistent radionuclides that were released during historical reactor operations at Hanford. However, we found no correlation between age of white sturgeon and long-lived radionuclides (i.e., ${ }^{90} \mathrm{Sr}$ and ${ }^{137} \mathrm{Cs}$ ). The low concentrations of radionuclides in sturgeon in our studies may be due to several factors, including low bioaccumulation, high turnover rate in tissues, and/or low availability or concentrations of radionuclides in the environment.

The retention time of radionuclides in biological issue is a key variable to be considered when comparing present-day radionuclide concentrations to historical values. Theoretically, some radionuclides accumulated by white sturgeon when the production reactors operated could still be measured. However, both physical decay of the radionuclide and biological turnover would reduce body burdens and our ability to detect residual compounds. Because no information on the behavior of radionuclides in white sturgeon tissues was available, we used values listed for human tissue in Napier et al. (1988) and for other fish species (Coughtrey and Thorne 1983; Gamez et al. 1991). Most long-lived radionuclides released to the Columbia River would turn over slowly in biological tissues (i.e., half-time $>1$ year). However, even at this rate, little of the absorbed radionuclide would be retained 20 to 30 years after uptake. Of the predominant radionuclides analyzed for, only $90 \mathrm{Sr}$ might be expected to be retained long enough in animal tissues to be detected 20 years after exposure (Dauble et al. 1988). Because of its valence state and chemical similarity to calcium, strontium is expected to accumulate in bone. However, white sturgeon are cartilaginous and therefore have different physiological characteristics than true bony fishes (teleosts). Thus, the mechanism for accumulation of ${ }^{90} \mathrm{Sr}$ by white sturgon is uncertain.

Measurable concentrations of radionuclides during the 1960 s were limited to the most abundant, yet short-lived radionuclides, present in Columbia River water and sediments. None of these short-lived radionuclides are present in detectable concentrations to 'ay. Strontium-90 has been routinely monitored and reported in Columbia River water since the sarly 1960s. However, the first record of ${ }^{90} \mathrm{Sr}$ in a Hanford Site monitoring report occurred in 1971 (Bramson and Corley 1972). Cesium-137 has been regularly reported in Columbia River fish and water since the use of gamma spectroscopy for analysis of radionuclides in the 1960s. A comparison of the 
relative concentrations of these relatively long-lived radionuclides measured in white sturgeon both during the time of peak reactor operations and during our recent studies is shown in Figure 7. Concentrations of industrial radionuclides in white sturgeon muscle have declined dramatically during the last 20 to 30 years.

Data from sturgeon collected in the mid-1960s generally indicate a lower level of contamination from radionuclides than that found in other species from that period (Foster and staff 1965). For example, mean and maximum bimonthly concentrations of $32 \mathrm{p}$ in whitefish fillets ranged as high as 1350 and $4900 \mathrm{pCi} / \mathrm{g} 32 \mathrm{P}$ in 1964 or an order of magnitude above of those found in white sturgeon muscle. Thus, the historical dose contribution from consumption of sturgeon would be less than the level resulting from the consumption of other more commonly harvested sports fish. This conclusion of lower comparable dose is also consistent with fisher surveys conducted in 1968, which indicated that sturgeon were caught less frequently than other species of gamefish in the Columbia River (Soldat 1970).

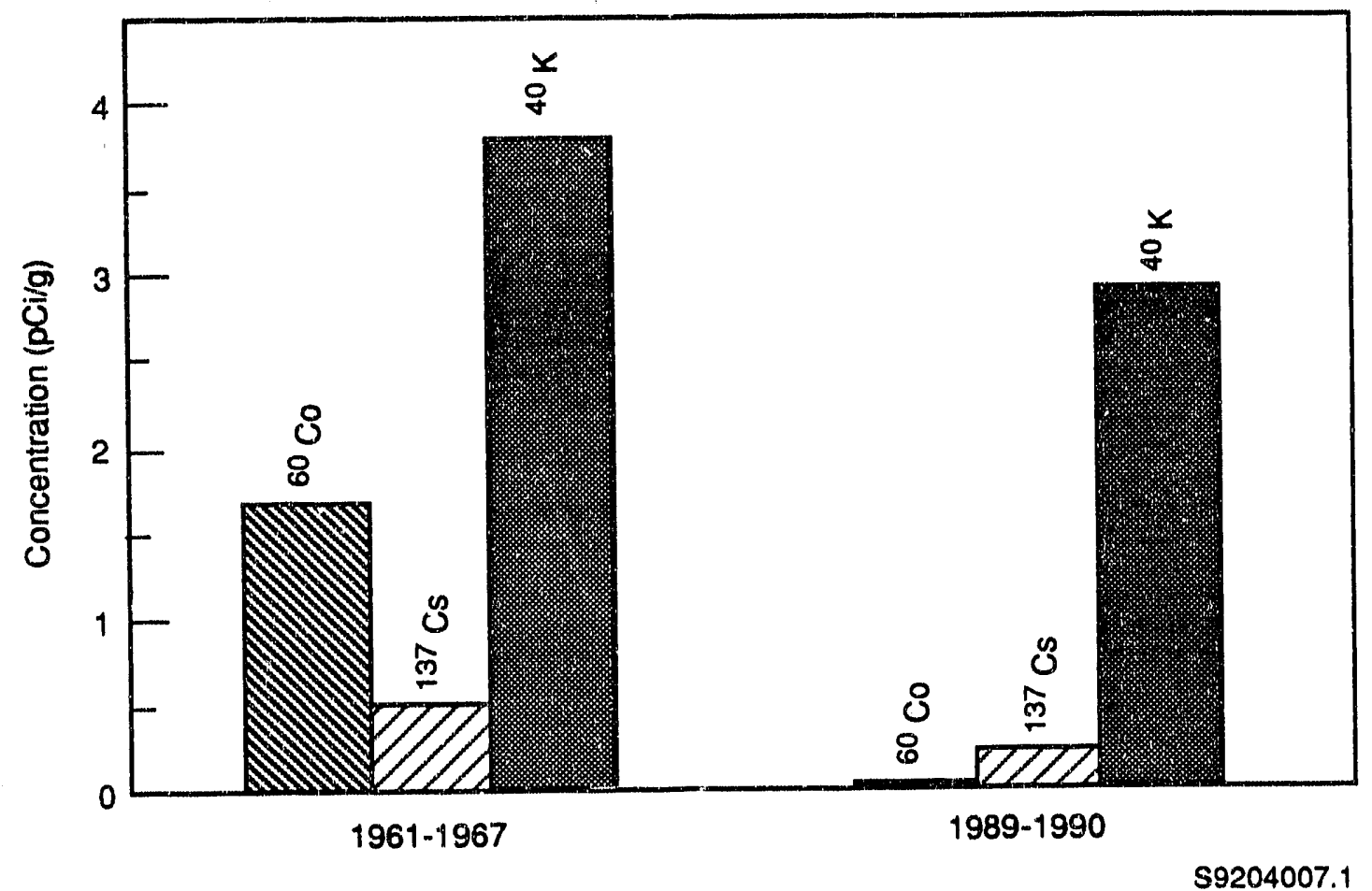

EIGURE 7. Comparison of Radionuclide Concentrations Found in White Sturgeon Muscle during Reactor Operations (1961 to 1967) Versus Present Day (1989 to 1990) 
The levels of radioactivity found in sturgeon during recent studies were comparable to or lower than levels routinely found in other species of fish collected from the Hanford Reach of the Columbia River (Jaquish and Bryce 1990). For example, the maximum concentration of ${ }^{137} \mathrm{Cs}$ in bass muscle was $0.05 \mathrm{pCi} / \mathrm{g}$ (from the 100-F slough). The current U.S. Department of Energy radiation limit for an individual member of the public is $100 \mathrm{mrem} / \mathrm{yr}$, and the average dose from natural sources is $300 \mathrm{mrem} / \mathrm{year}$ (DOE 1990). Dose rates from Hanford operations in the early to mid-1960s were 80 to 100 mrem whole-body dose, primarily resulting from ${ }^{32} \mathrm{P}$ and $65 \mathrm{Zn}$ in fish flesh. In 1991, the potential annual dose to consumers resulting from the consumption of Columbia Piver fish (40 kg/year) was 0.008 mrem (Woodruff et al. 1991). Assuming that consumption of sturgeon was equivalent to consumption of other Columbia River fish, the expected doses would be even lower. Thus, the near background levels of radionuclides found in muscle of white sturgeon do not pose a health risk to humans eating these tissues. 


\section{REEERENCES}

Beasley, T. M., and C. D. Jennings. 1984. "Inventories of $239,240 \mathrm{Pu},{ }^{241} \mathrm{Am},{ }^{137} \mathrm{Cs}$, and 60 Co in Columbia River Sediments from Hanford to the Columbia River Estuary." Environ. Sci. Technol. 18:207-212.

Beasiey, T. M., L. A. Ball, J.A. Andrews, III, and J. E. Halverson. 1981. Hanford-Derived Plutonium in Columbia River Sediments. Science. 214:913-915.

Bosley, C. E. , and G. F. Gately, 1981. Rolvchlorinated Biphenyls and Chlorinated Pesticides in Columbia River White Sturgeon (Acipenser transmontanus). U.S. Fish and Wildlife Service Report, Nordland, Washington.

Bramson, P. E., and J. P. Corley, 1972. Environmental Surveillance at Hanford for CY-1971. Addendum. BNWL-1683, Pacific Northwest Laboratory, Richland, Washington.

Bramson, P. E., and J. P. Corley. 1973. Environmental Suryeillance at Hanford for CY-1972. BNWL-1727, Pacific Northwest Laboratory, Richland, Washington.

Corley, J. P., and Environmental Evaluations Staff. 1969. Evaluation of Radiological Conditions in the Vicinity of Hanford for 1967. BNWL-983, Pacific Northwest Laboratory', Richland, Washington.

Coughtrey P. J., and M. C. Thome. 1983. Radionuclide Distribution and Transport in Terrestrial and Aquatic Ecosystems. Vols. I \& II, A.A. Balkena, Rotterdam, Netherlands.

CRC Handbook of Chemistry and Physics. 1983. CRC Press, Boca Raton, Florida.

Cushing, C. E., D. G. Watson, A. J. Scott, and J. M. Gurtisen. 1980. Decline of Radionuclides in Columbia River Biota. PNL-3269, Pacific Northwest Laboratory, Richland, Washington.

Cushing, C. E., W. H. Rickard, and D. G. Watson. 1988. Radionuclide Accumulation by Aquatic Biota Exposed ie Contaninated Water in Artificial Ecosysterns Before and After its Passage Through the Ground. NUREG/CR-5047 (PNL-5590), prepared by Pacific Northwest Laboratory, for the U.S. Nuclear Regulatory Commission Washington, D.C.

Dauble, D. D., T. M. Poston, and R. L. Newell. 1988. Assessment of Aquatic Organisms as Bioindicators of Historical Radionuclide Release to the Columbia River. PNL-6795, Pacific Northwest Laboratory, Richland, Washington.

Davis, J. J., D. G. Watson, and C. C. Palmiter. 1956. Radiobiological Studies of the Rolumbia River through December. 1955. HW-36074, Hanford Atomic Products Operation, Richland, Washington.

Departunent of Energy (DOE). 1990. DOE Order 5500.5. Radiation Protection of the Public and Environment.

Emery, R. M., D. C. Klopfer, and M. C. McShane. 1978. "The Ecological Export of Plutonium from a Reprocessing Waste Pond." Health Physics 34:255-268. 
Foster, R. F., and Environmental Studies \& Evaluation Staff. 1962. Evaluation of Radiological Conditions in the Vicinity of Hanford for 1961. HW-71999, Hanford Atomic Products Operation, Richland, Washington.

Foster, R. F., and Environmental Studies \& Evaluation Staff. 1963. Evaluation of Radiological Conditions in the Vicinity of Hanford for 1962. HW-76526, Hanford Atomic Products Operation, Richland, Washington.

Foster, R. F., and Environmental Studies \& Evaluation Staff. 1964. Evaluation of Radiological Conditions in the Vicinity of Hanford for 1963. HW-80991, Hanford Atomic Products Operation, Richland, Washington.

Foster, R. F., and Environmental Studies \& Evaluation Section Staff. 1965. Evaluation of Radiological Conditions in the Vicinity of Hanford for 1964. BNWL-90, Pacific Northwest Laboratory, Richland, Washington.

Foster, R. F., and Environmental Studies Section Staff. 1966. Evaluation of Radiological Conditions in the Vicinity of Hanford for 1965. BNWL -316. Pacific Northwest Laboratory, Richland, Washington.

Gamez, L. S., M. G. Marietta, and D. W. Jackson. 1991. Compilation of Selected Marine Radioecological Data for the Formerly Utilized Sites Remedial Action Program: Summaries of Available Radioucological Concentration Factors and Biological Half-lives. SAND89-1585, Sandia National Laboratories, Albuquerque, New Mexico.

Hauschild, W. L., H. H. Stevens, Jr., J. L. Nelson, and G. R. Dempster, Jr. 1971. Badionuclides in Transporr in the Columbia River from Pasce to Yancouver. Washington. Openfile Report, U.S. Department of the Interior Geological Survey, Portland, Oregon.

Hauschild, W. L., G. R. Dempster, Jr., and H. H. Stevens, Jr. 1975. Distribution of Radionuclides in the Columbia River Stream Bed. Hanford Reservation to Longview Washington. Geological Survey Professional Paper 433-0 U.S. Government Printing Office, Washington, D.C.

Haynes, J. M., R. H. Gray, and J. C. Montgomery. 1978. "Seasonal Movements of White Sturgeon (Acipenser transmontanus) in the Mid-Columbia River." Irans.Am. Fish. Soc. 107:275-280.

Hess, S. 1984. Age and Grows of White Sturgeon in the Lower Columbia River 1980-1983. Oregon Department of Fish and Wildlife Report, Portland, Oregon.

Honstead, J. F., and Environmental Studies Section Staff. 1967. Evaluation of Radiological Conditions in the Vicinity of Hanford for 1966. BNWL-439, Pacific Northwest Laboratory, Richland, Washington.

Jaquish, R. E., and R. W. Bryce. 1990. Hanford Site Environmental Report for Calender Year 1989. PNL-7346, Pacific Northwest Laboratory, Richland, Washington.

Napier, B. S., R. A. Peloquin, D. L. Strenge, and J. V. Ramsdell. 1988. GENIL-The Hanford Environrnental Radiation Dosimetry Software Svstem. Volume 3: Code Maintenance Manual. PNL-6584, Pacific Northwest Laboratory, Richland, Washington. 
Page, T. L., R. H. Gray, and E. G. Wolf. 1976. Einal Report on Aquatic Ecological Studies Conducted at the Hanford Generaring Project. 1973-1974. Prepared for Washington Public Power Supply System by Battelle, Pacific Northwest Laboratories, Richland, Washington.

Perkins, R. W., J. L. Nelson, and W. L. Hauschild. 1966. "Behavior and Transport of Radionuclides in the Columbia River Between Hanford and Vancouver, Washington. Limnol. Oceanogr. H: 235-248.

Poston, T. M., and D. C. Klopfer. 1986. Aliterature Review of the Concentration Ratios of Selected Radionuclides in Ereshwater and Marine Fish. PNL-5484, Pacific Northwest Laboratory, Richland, Washington.

Robeck, G. G., C. Henderson, and R. C. Palenge. 1954. Water Quality Studies on the Columbia River. U.S. Department of Health, Education, and Welfare, Cincinnati, Ohio.

Robertson, D. E. and J. J. Fix. 1977. Association of Hanford Origin Radionuclides with Columbia River Sediment. BNWL-2305. Pacific Northwest Laboratory, Richland, Washington.

Semakula, S. N., and P. A. Larkin. 1968. "Age, Growth, Food, and Yield of the White Sturgeon (Acipenser transmontanus) of the Fraser River, British Columbia." L.Fish.Res. Bd. Canada. 25:2598-2602.

Soldat, J. K. 1970. "A Statistical Study of the Habits of Fisherman Utilizing the Columbia River below Hanford." In Enyironmental Survejllance in the Vicinity of Nuclear Eacilities ed. W. C. Reinig, pp. 302-308. Charles C. Thomas, Springfield, Illinois.

Toombs, G. L., and P. B. Cutler. 1968. Lower Columbia River Environmental Radiobiological Survey in Oregon. Comprehensive Final Report 1961-1962. Oregon State Board of Health, Portland, Oregon.

Watson, D. G., C. E. Cushing, C. C. Coutant, and W. L. Templeton. 1970. Radioecological Studies on the Columbia River. Part L and II. BNWL,-1377, Pacific Northwest Laboratory, Richland, Washington.

Woodruff, R. K., R. W. Hanf, M. G. Hefty, and R. E. L.undgren, eds. 1991. Hanford Site Environmental Report for Calender Year 1990. PNL-7930, Pacific Northwest Laboratory, Richland, Washington. 
APPENDIX A

SUMMARY OE HISTORICAL DATA 


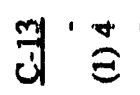

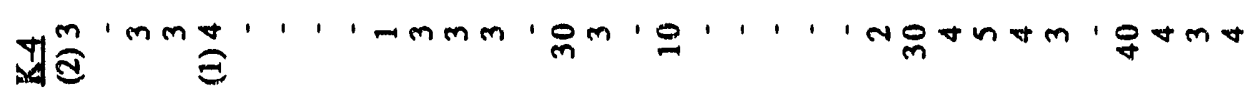

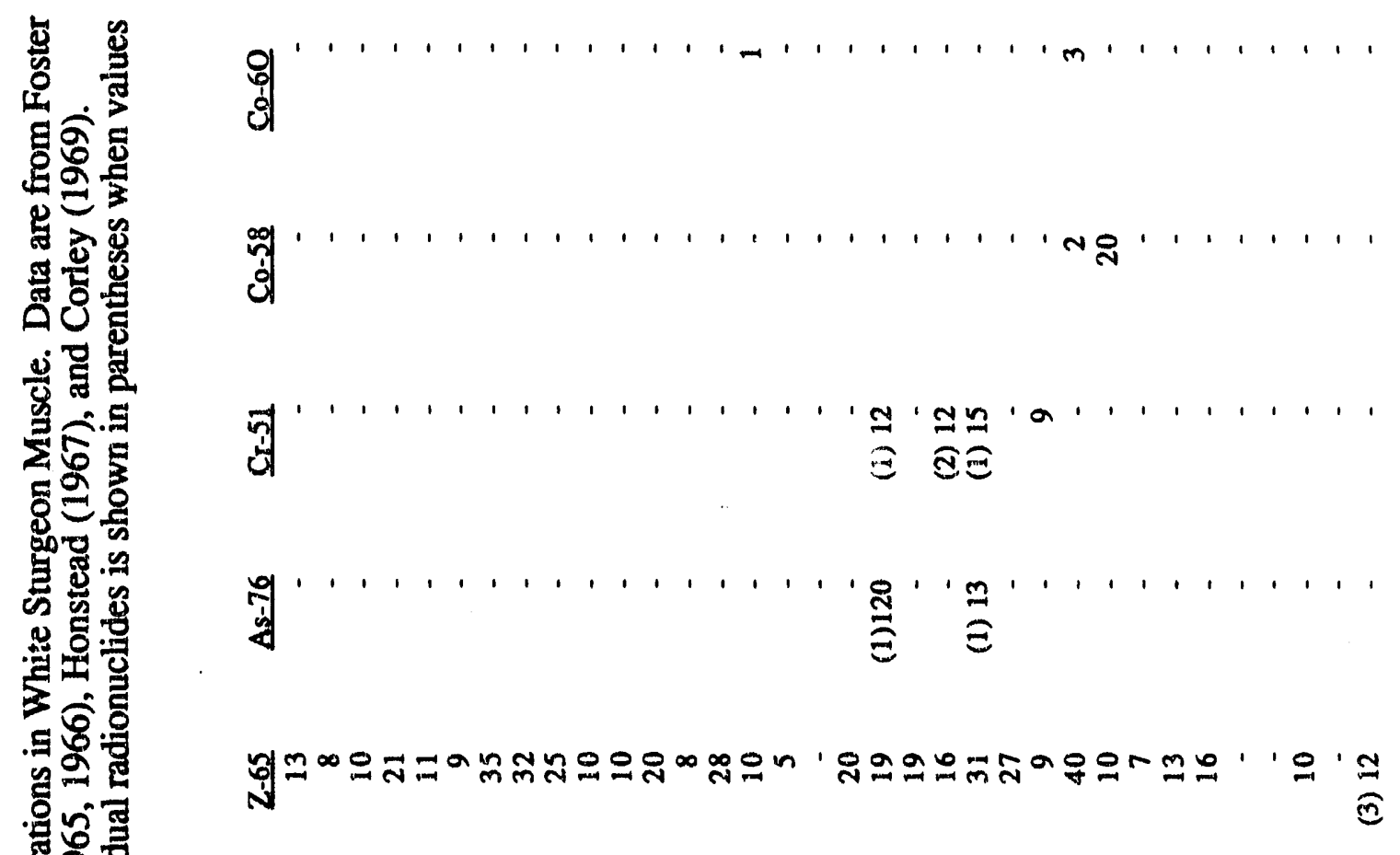

กำ

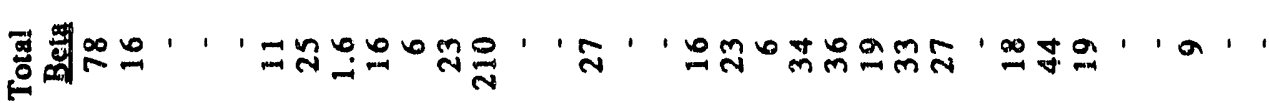

曹

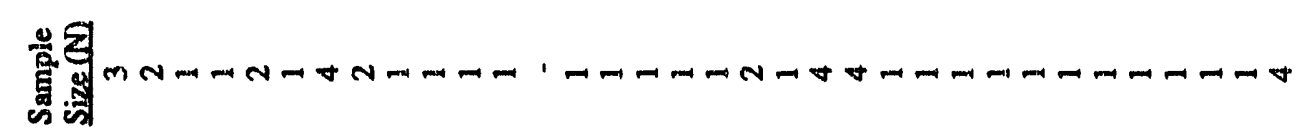

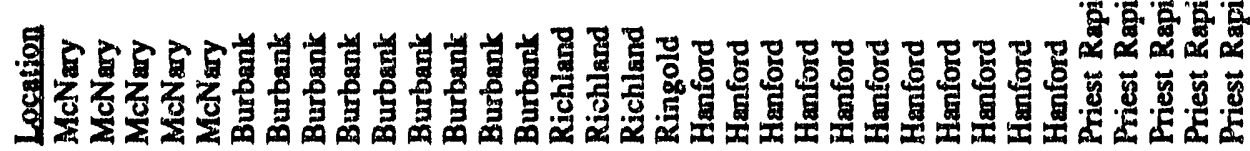

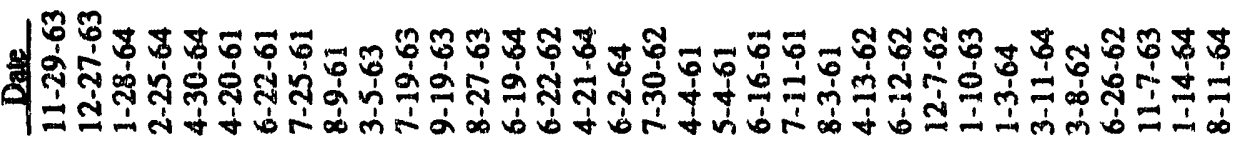


$\stackrel{\text { s }}{\underline{5}}$

勿 '

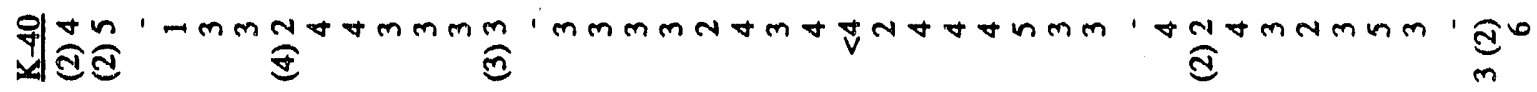

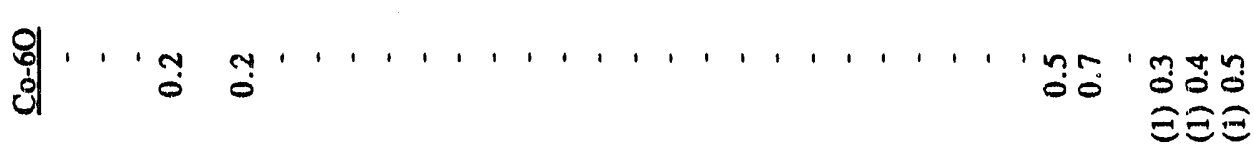

?ุ่ 'mọ' ợn ำ

㖓

妾

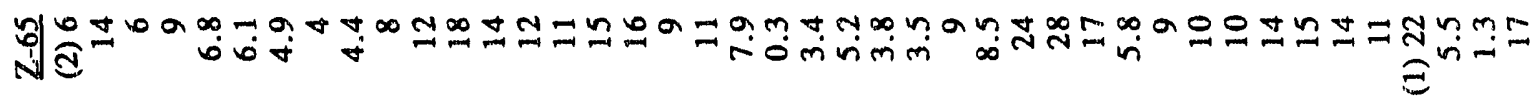
匈 窟 :

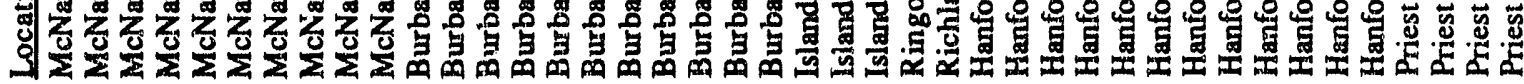




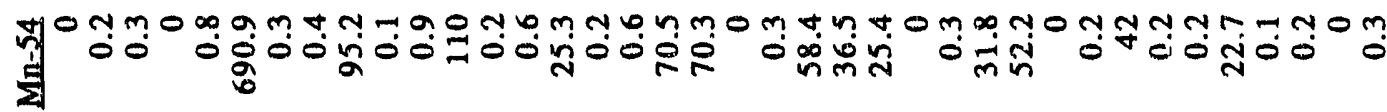

|

4

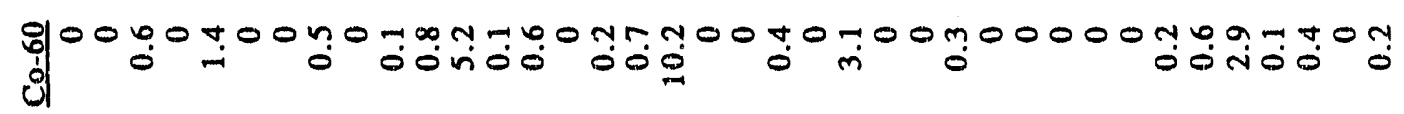
엄

年

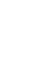

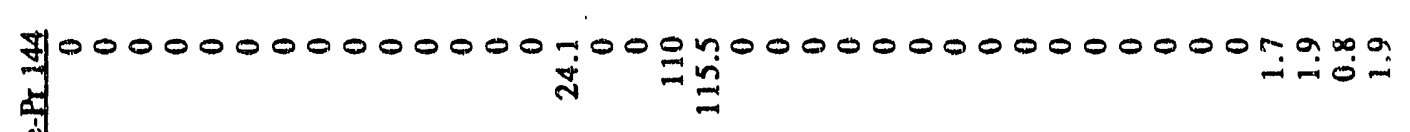

⿹勹䶹

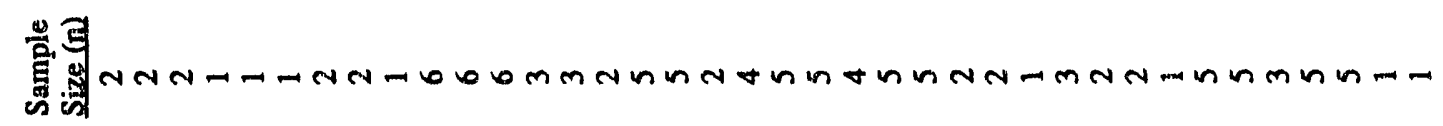
ఎ 


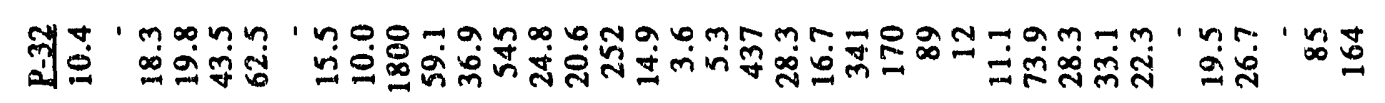

$$
\begin{aligned}
& \text { 娄………ำ } \\
& \text { ฟी }
\end{aligned}
$$

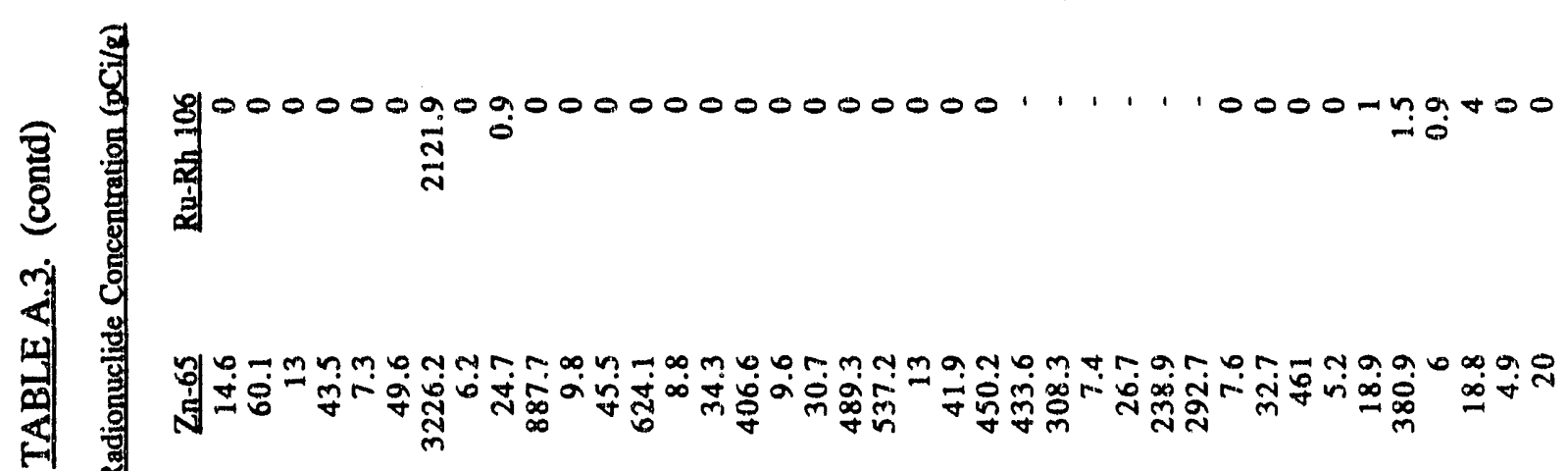

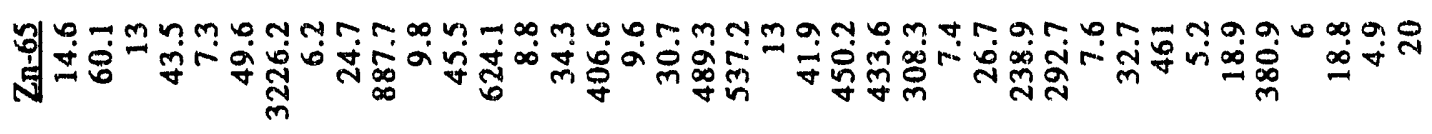

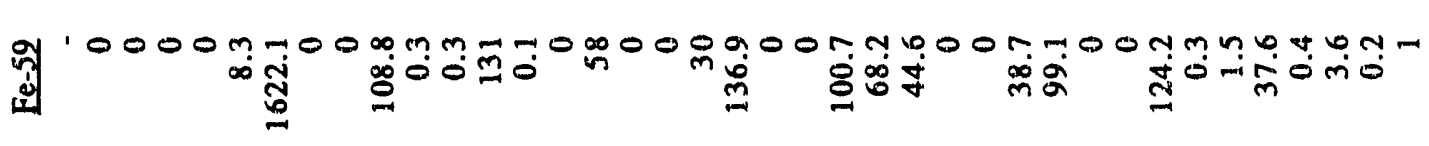

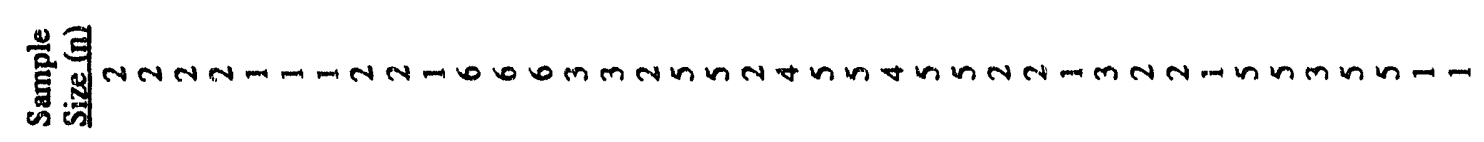

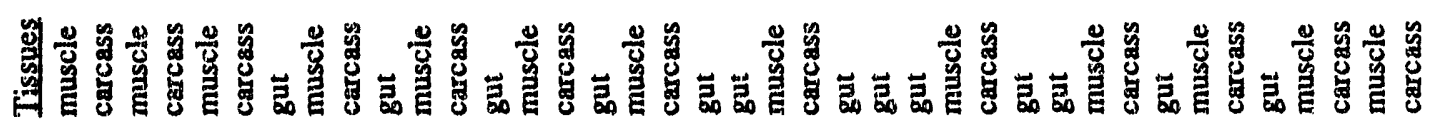

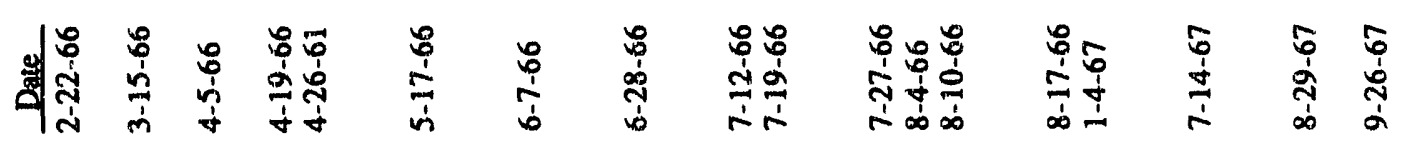




\section{APPENDIX B}

\section{DATA EROM CURRENT STUDIES}


สิษ

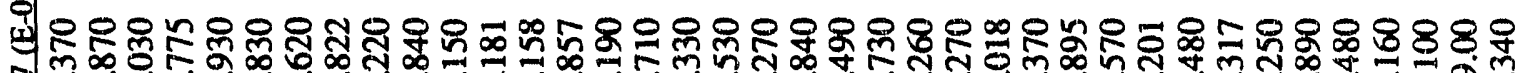
ติ है।

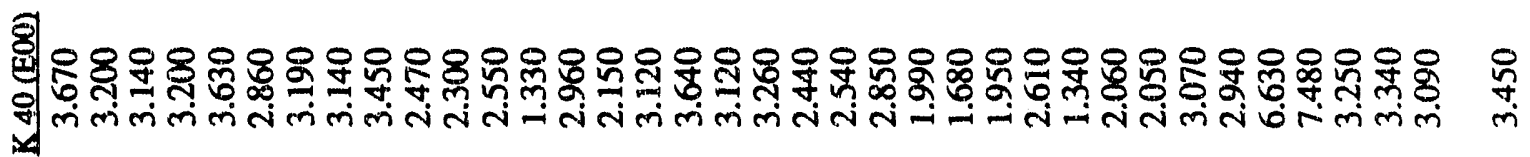

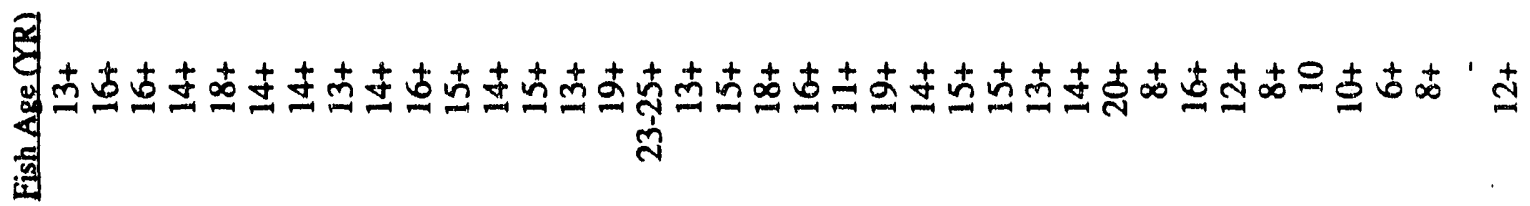
:ृ8

$\overline{0}$ 范

茐

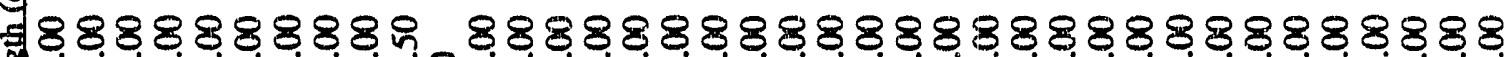

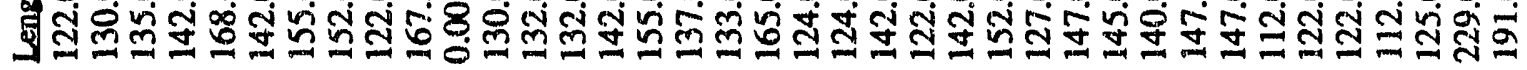

돌 윰

兽怘

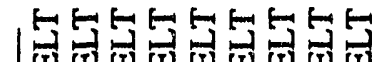

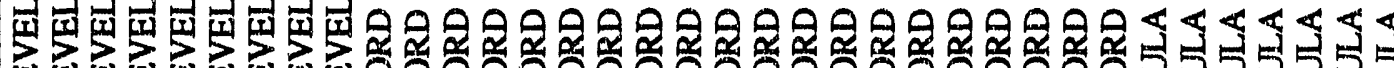

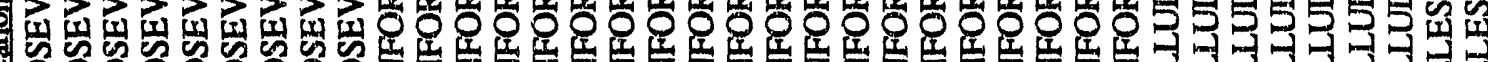
8888888888

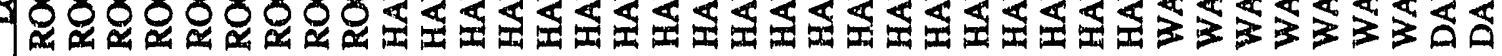

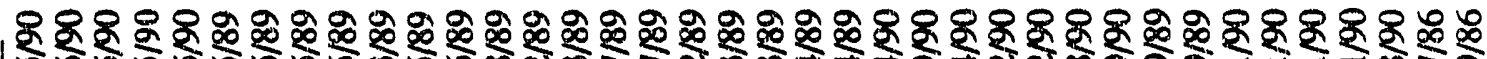

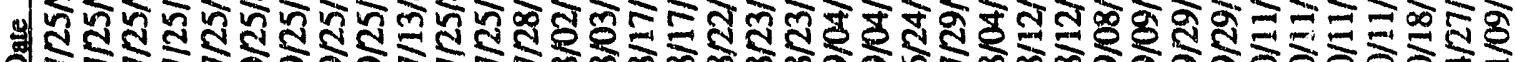

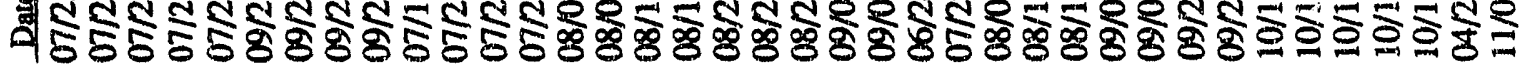

B. 1 


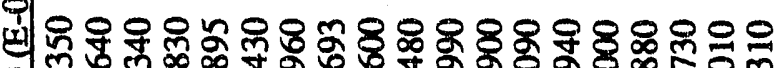
ণं भं

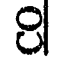

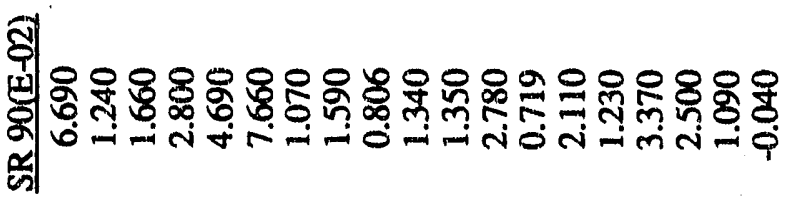

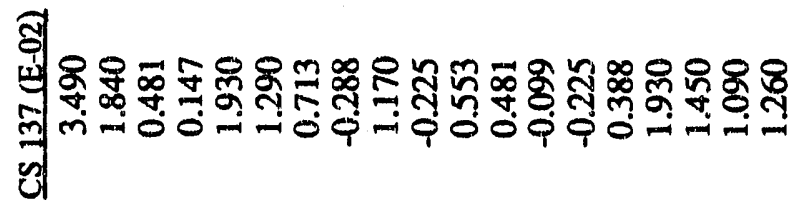

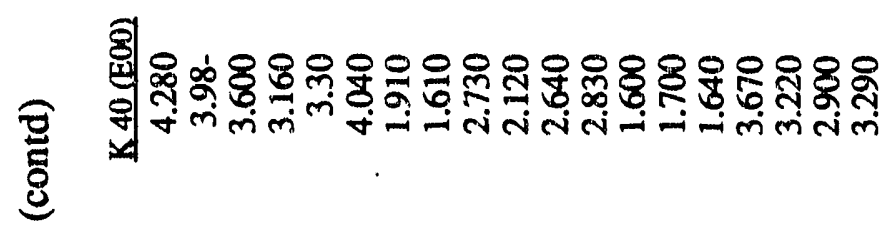

(1)

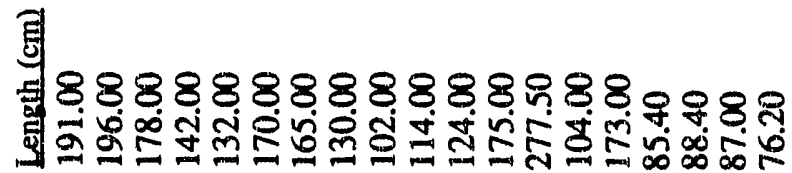

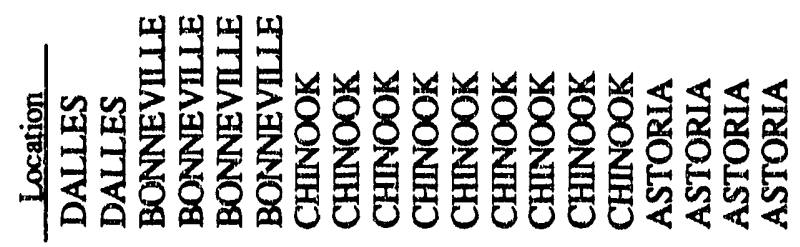

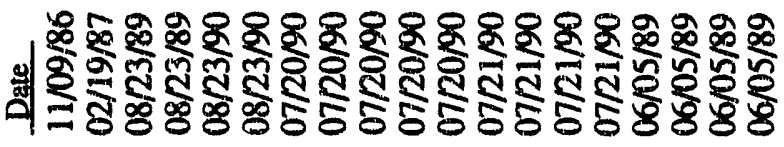

B. 2 


\section{DISTRIBUTION}

No. of

Copies

\section{OEFSITE}

12 DOE/Office of Scientific and Technical Information

Ernie Brannon

Aquaculture Institute

University of Idaho

Moscow, ID 83843

John DeVores

P.O. Box 999

Battleground, WA 98604

John L. Erickson

Division of Radiation Protection

Washington State Department of

Health

Air Industrial Center, Bldg. \#5

LE-13

Olympia, WA 98504

Fred Holm

Division of Fish and Wildlife

Bonneville Power Administration

P.O. Box 3621

Portland, OR 97208

Art Johnson

Washington State Department

of Ecology

Air Industrial Building \#8

7171 Queen Water Lane

Olympia, WA 98504-7710

R. D. Paris

Manager, Radiation Control Section

Oregon State Health Division

1400 S.W. 5th Ave.

Portland, OR 97201

Steve Parker

Yakima Indian Nation

P.O. Box 151

Toppenish, WA 98948
No. of

Copies

Dave Serdar

Washington State Department of Ecology

Air Industrial Building \#8

7171 Queen Water Lane

Olympia, WA 98504-7710

G. E. Toombs

Radiation Control Section

Environmental Radiation Surveillance

Supervisor

Oregon State Health Division

1400 S.W. 5th Ave.

Portland, OR 97201

\section{ONSITE}

4 DOE Richland Field Office

R. F. Brich

R. W. Hildebrand

R. A. Holten

M. W. Tiernan

2 Westinghouse Hanford Company

M. R. Adams

G. D. Carpenter

49 Pacific Northwest Laboratory

D. D. Dauble (20)

R. H. Gray

R. W. Hanf

R. E. Jaquish

R. E. Lundgren

T. M. Poston (5)

K. R. Price (5)

W. L. Templeton

D. G. Watson

R. K. Woodruff (5)

SESP Historical Files/R. K. Woodruff

Publishing Coordination

Technical Report Files (5) 
No. of

UC-603

Copies

Routing

R. M. Ecker

J. W. Falco

M. J. Graham

R. L. Skaggs

H. E. Westerdahl

P. C. Hays (last) 

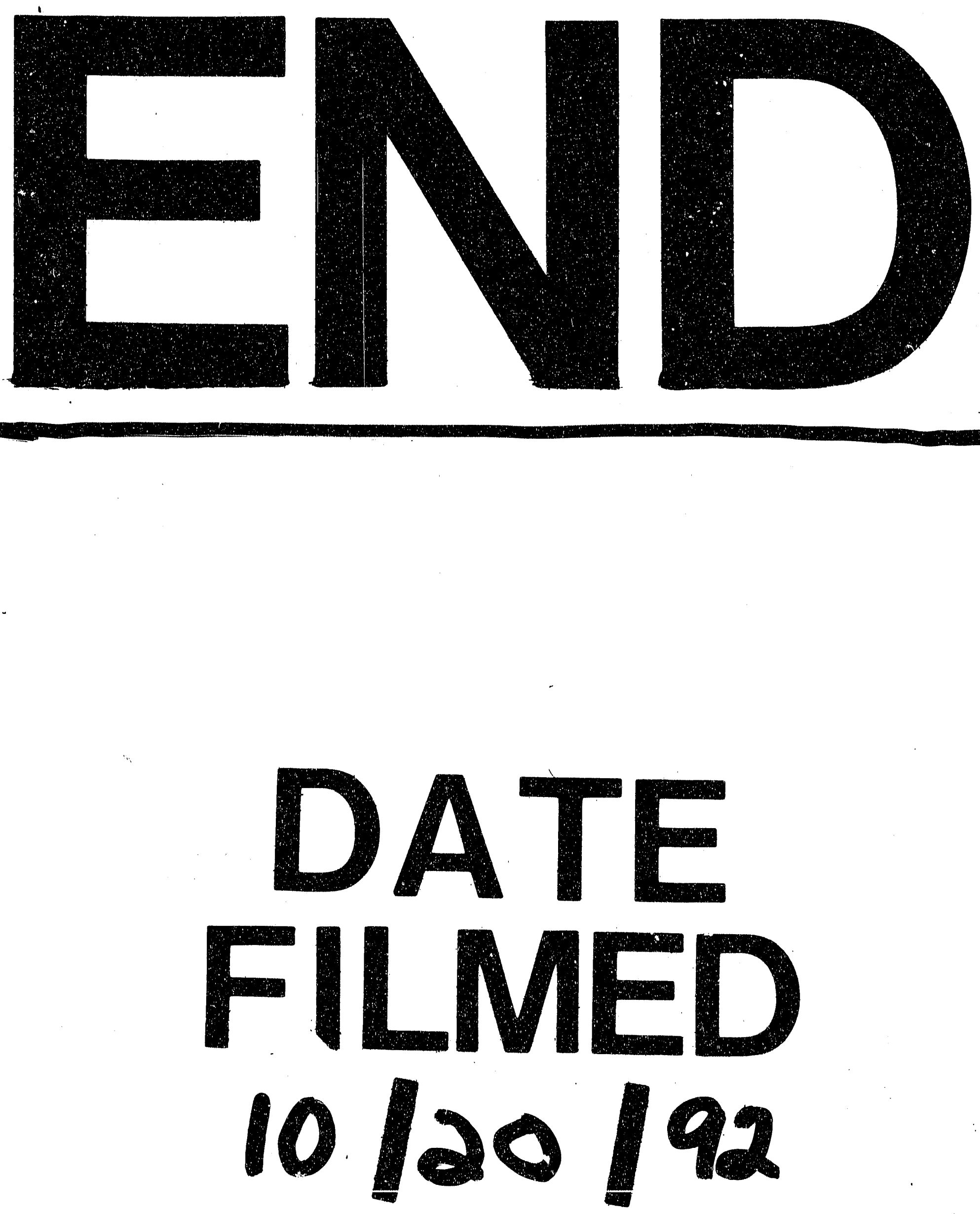

흘 